NBER WORKING PAPER SERIES

\title{
THE NEW DEAL AND THE ORIGINS OF THE MODERN AMERICAN REAL ESTATE LOAN CONTRACT
}

\author{
Jonathan Rose \\ Kenneth A. Snowden \\ Working Paper 18388 \\ http://www.nber.org/papers/w18388 \\ NATIONAL BUREAU OF ECONOMIC RESEARCH \\ 1050 Massachusetts Avenue \\ Cambridge, MA 02138 \\ September 2012
}

The authors thank the participants in the Microeconomics of the New Deal conference and the Greater Boston Urban and Real Estate Economics Seminar, especially Alexander Field, Paul Willen, Price Fishback, and Bill Collins. Snowden acknowledges the financial support provided by National Science Foundation Grant SES-1061927. The views presented in this paper are solely those of the authors and do not necessarily represent those of the Federal Reserve Board or its staff, or the National Bureau of Economic Research. NBER working papers are circulated for discussion and comment purposes. They have not been peer reviewed or been subject to the review by the NBER Board of Directors that accompanies official NBER publications. The views expressed herein are those of the authors and do not necessarily reflect the views of the National Bureau of Economic Research.

NBER working papers are circulated for discussion and comment purposes. They have not been peerreviewed or been subject to the review by the NBER Board of Directors that accompanies official NBER publications.

(C) 2012 by Jonathan Rose and Kenneth A. Snowden. All rights reserved. Short sections of text, not to exceed two paragraphs, may be quoted without explicit permission provided that full credit, including (C) notice, is given to the source. 
The New Deal and the Origins of the Modern American Real Estate Loan Contract

Jonathan Rose and Kenneth A. Snowden

NBER Working Paper No. 18388

September 2012

JEL No. G21,N21,N22,O33

\begin{abstract}
$\underline{\text { ABSTRACT }}$
The introduction of the direct reduction (fully-amortized) loan contract to the U.S. residential mortgage market is an important instance of financial innovation. We describe the adoption of this contract within the building and loan (B\&L) industry beginning in the 1880s and culminating in the 1930s. A long chain of complementary innovations at B\&Ls gradually reduced the costs of adoption, leading to moderate use by the 1920s. The poor performance of traditional contracts during the crisis of the 1930s then radically altered the adoption calculus. At this point a new system of federal savings and loan charters incorporated many of the innovations that had been adopted within the small segment of the B\&L industry that had introduced direct reduction lending by the 1920s. The B\&L transition in mortgage contracts occurred primarily in the conventional loan market because B\&Ls, unlike other lenders, generally avoided the use of the new FHA insurance program.
\end{abstract}

Jonathan Rose

Federal Reserve Board

20th \& C Streets, N.W.

Washington, D.C. 20551

jonathan.d.rose@frb.gov

Kenneth A. Snowden

Bryan School of Business and Economics

P.O. Box 26165

University of North Carolina at Greensboro

Greensboro, NC 27402

and NBER

snowden@uncg.edu 


\section{Introduction}

During the 1930s, the increased use of direct reduction loan contracts (i.e., fully amortized loans) reshaped the U.S. residential mortgage market. This transition is often described as a rapid move away from short-term, interest-only, balloon loans prior to the Great Depression, resulting from the success of two New Deal programs that used the direct reduction contract: loan insurance through the Federal Housing Administration (FHA), and refinancing through the Home Owners Loan Corporation (HOLC). ${ }^{1}$ This popular account captures important parts of the truth, but it misses much more. Neither the FHA nor the HOLC were the first in the U.S. to use the direct reduction contract for residential real estate loans. That honor belongs to a segment of the building and loan (B\&L) industry, historically the largest institutional source of residential real estate loans. ${ }^{2}$ B\&Ls introduced the direct reduction contract in the 1880 s and used it continually thereafter. ${ }^{3}$ As is the case with many innovations, the widespread adoption of this contract did not follow immediately after its inception, nor did it necessarily appear inevitable ex ante. In this paper, we identify the forces that drove the adoption of the direct reduction contract by B\&Ls after 1930 and explain why the same forces did not lead to more widespread adoption during the previous fifty years.

The bulk of the B\&L industry long used neither the direct reduction contract nor the short-term balloon contract. Instead, most B\&Ls relied heavily on the traditional B\&L share accumulation loan that dates back to the 1830s in the U.S. and the 1780s in England. In a share accumulation loan, a borrower committed to purchasing equity shares in his B\&L each month until the shares, plus retained dividends, equaled the value of the loan. The repayment period usually lasted around twelve years, with the exact duration and interest cost depending on the dividend rate that the borrower earned on the accumulated shares. In comparison, a direct

\footnotetext{
${ }^{1}$ See, for example, Green and Wachter (2005), Emmons (2008), Gruenberg (2007), Center for American Progress (2011), or Zandi and deRitis (2011), among many others. Jaffee (1975) is a notable exception. We build on Jaffee’s work by considering the mortgage loan contract from a financial innovation point of view.

${ }^{2}$ Throughout the paper we describe these institutions as building and loan associations. During the 1930s and 1940s, the industry transitioned to the "savings and loan" nomenclature.

${ }^{3}$ Of separate interest is the adoption of the direct reduction contract in the farm sector. See Snowden (2010) for an overview. Between 1908 and 1912 a "Rural Credits Movement" called for federal intervention into the mortgage market so that farmers in the U.S. could use long-term, fully-amortized mortgage loans that had been written for decades within European covered bond systems (Herrick and Ingalls, 1915). The movement led to the passage of the Federal Farm Loan Act of 1916 which created a publicly-sponsored cooperative mortgage lending system alongside a federally-chartered system of private joint-stock mortgage banks. Lenders in both systems were required to write long-term amortized loans so that they could not deal in the standard short-term, balloon loan (Schwartz, 1938, pp. 21-22).
} 
reduction loan delivers more certainty to borrowers. Since the non-interest portion of each payment directly reduces the amount of outstanding principal debt, the maturity date is known from the outset as well as the ultimate interest cost.

Despite the greater certainty that direct reduction loans provided to B\&L borrowers, the traditional share accumulation loan remained in wide use within the industry until it was rapidly abandoned in favor of the direct reduction loan during the 1930s. Three data sources are used here to establish that timeline. First, an 1893 federal census of B\&L activities shows that the share accumulation contract dominated the B\&L industry at that time. The next period we examine is the 1920s, using data from a retrospective NBER survey conducted during the 1940s. This evidence, though flawed, indicates that direct reduction contracts were adopted a bit more widely by that time, but the share accumulation contract was still much more common. The share accumulation contract was then rapidly and broadly abandoned in favor of the direct reduction contract starting in the mid-1930s, particularly around 1935. To establish the speed of this transition, we have gathered annual data on contract use from reports of B\&L regulators in sixteen states, and from more qualitative accounts in several additional states. This evidence establishes for the first time the rapid and widespread adoption during the late 1930s of direct reduction loans within the market for non-insured (conventional) real estate loans.

It is tempting to consider the rapid 1930s transition to direct reduction loans as an isolated instance of financial innovation. The explanation offered here, in contrast, views the transition as the culmination of a long chain of innovations within the conventional residential loan market, centered in the B\&L industry, which gained considerable momentum in that decade. In other words, we suggest the correct unit of innovation is a suite of organizational and financial policies that complemented and enabled the use of the direct reduction contract, rather than just the loan contract itself. The outline of our argument is as follows.

When adopting the direct reduction contract a B\&L had to weigh its attractiveness to borrowers against three offsetting costs: the loss of credit risk sharing with borrowers, the costs of organizational and accounting changes, and the potential loss of mutuality which allowed B\&Ls to avoid federal taxation. Incremental innovation at B\&Ls over several decades gradually lowered these costs to the point at which they were broadly balanced with the benefits of adoption by the 1920s. Borrowers' demands then changed rapidly during the 1930s as they became acutely aware of the great risks that the share accumulation contract placed on them 
during a mortgage crisis. The events of the 1930s do not appear to have sparked the innovation of new contracts. Rather, existing practices became unsustainable, encouraging the adoption of different contracts.

In this context, New Deal policy that encouraged direct reduction loans did not act in isolation, but rather built on past innovations. Federal savings and loan charters required direct reduction lending, directly emulating a small segment of the B\&L industry that federal officials admired. Liability insurance through the Federal Savings and Loan Insurance Corporation helped restructure the liability side of B\&L balance sheets to accommodate the loss of credit risk sharing and mutuality inherent to the new loan format. Though FHA insurance of direct reduction loans likely changed the competitive environment for B\&Ls, it is revealing that B\&Ls made the transition to such loans while largely avoiding the new FHA program and focusing their lending activities within the much larger uninsured (conventional) market.

The discussion here focuses on the use of amortization, as does the paper in general. Of course, the risks in a loan contact are influenced by all of its features, including the term, leverage, interest rate and method of repayment. Lenders compete for borrowers by adjusting any or all of the four. However, we identify amortization as the key development in the 1930s that drove the other changes in loan contracts during that decade. Full amortization was required to reduce the risk associated with higher leverage and longer maturities, and its absence had become the key constraint on loan contract design in the early twentieth century. ${ }^{4}$ The short term balloon loan, in wide use among non-B\&L lenders, was emblematic of older ways of assessing risk that emphasized borrowers’ equity rather than capacity to pay.

Many readers will also identify the modern American loan contract with the use of fixed rates over long periods of time. However, innovations to deal with interest rate risk have largely been a development confined to the postwar era and were not prominent during the historical period considered in this paper.

\section{Loan contracts at B\&Ls before 1930}

In this section, we have two goals. First, we begin with the early history of the B\&L industry in order to understand how the share accumulation contract came to be the default

\footnotetext{
${ }^{4}$ See for example, Colean (1944). Colean helped design the FHA's mortgage loan program, and argues that amortization was the most important change of the period and led to a restructuring of credit standards with more focus on consumers' ability to pay, similar to practices common for other consumer installment loans.
} 
contract in that industry. This history shows that, at first, the share accumulation contract for borrowers was not a choice of an association but rather the foundation of B\&L financial structure and inseparable from it without the subsequent history of innovations in that structure. Our second goal is to identify the three main costs of switching from share accumulation loans to direct reduction loans and describe how B\&Ls addressed these costs. These costs were not insurmountable, and indeed between 1880 and 1930 a moderate portion of the industry was willing to bear them in order to adopt direct reduction loans. By 1930, techniques for lowering these costs had been in use for years and were disseminated quickly to the rest of the industry during the next decade, helping to speed the adoption process as associations sought to jettison increasingly unpopular share accumulation loans.

A theme of this section is that the adoption of direct reduction loans was affected by its interaction with other B\&L practices, which evolved in the century before 1930. Rosenberg (1982) provides a useful conceptual framework for explaining the trajectory of innovations in the B\&L industry. He emphasizes that the appropriate unit of innovation is rarely a single invention. Instead, major productivity improvements are driven by the accumulation of incremental changes that follow a path shaped by compatibility with existing practices. Taken in this light, the transition from share accumulation to direct reduction contracts among B\&Ls cannot be explained simply by comparing the two loan contracts in isolation, as the choice between the two was also conditioned on innovations in other B\&L practices.

\subsection{The place of share accumulation contracts in B\&L operations}

The share accumulation plan was the contractual foundation of the building and loan movement in the U.S. ${ }^{5}$ In the earliest B\&Ls, all members joined in order to eventually become borrowers. From the outset each member would commit to accumulate shares of the size he needed to pay for a home, through the payment of compulsory monthly dues. For example, if a member desired to accumulate $\$ 1000$ for a house, he would subscribe for five shares with maturity value of \$200 each. Members would then take turns in borrowing from the pot of money created by these dues. By the time it was a member's turn to borrow, he would have already accumulated part of his shares (and retained dividends) that would eventually be used to

\footnotetext{
5 This section gathers information contained in Bodfish and Theobald (1938), pp. 30-49; Ewalt (1962), pp. 370-395; Clark and Chase (1927), pp. 32-62; and Bodfish (1931), chapters 4-7.
} 
pay off the loan in full. ${ }^{6}$

Share accumulation loans were straight, balloon loans that also required the creation of a sinking fund in the form of shares to repay the loan at maturity. Thus, they were quite different than balloon loans offered by other lenders that did little to require borrowers plan for repayment. Of course, the B\&L loan required not just monthly dues but also interest payments, on the full amount of the loan since that amount remained outstanding until the shares matured and the loan was cancelled. However, as a borrower's sinking fund grew, it would accumulate retained dividends that in some sense offset the interest payments. The pace of these retained dividends would determine the maturity of the loan, which was indefinite but typical profitability delivered a term of 11-12 years. ${ }^{7}$

These original associations terminated once the shares reached their maturity value and, by design, each member had accumulated enough savings to have paid for a house. Consequently, they are known today as terminating associations. The design was borrowed from the structure of early English building societies and can be traced back to the 1780s in England and the 1830s in the United States.

From the 1830 s to the 1880 s, B\&Ls evolved away from terminating associations, which were limited to serving small groups of prospective homeowners who were ready and willing to commit to a strict, compulsory savings plan over the same horizon, roughly twelve years. This organizational structure had its merits but also several shortcomings. It generally limited the size of operations, and was not designed to attract non-borrowing savers. It also presented the difficulty of perfectly matching the pace of borrowing with the pace of members' contributions. The latter issue was addressed by the first major change in B\&L structure, dating roughly to the 1850s when some associations began to avoid termination by issuing multiple series of shares spaced over time, rather than retaining the terminating association practice of issuing a single series of shares at one time. Eventually these so-called serial associations also dropped the requirement that all members borrow. Such a requirement had been important to terminating associations to ensure that available funds would be used as they became available, but in serial

\footnotetext{
${ }^{6}$ While the small size of traditional B\&Ls suggests a similarity with micro-credit institutions, Snowden (1997) finds that the small size was rather a choice of the associations' management (e.g. local builders) who had little desire to manage associations larger than what was necessary to provide financing for their other businesses

${ }^{7}$ Until the maturity value was reached, the rules regarding payment of dues and dividends were strict. Members were fined if they missed or were late paying dues. Members were also required to reinvest dividends in their share accounts, and stood to lose some accumulated dividends, and perhaps even some paid-in dues, if they withdrew before the shares matured.
} 
associations each series of members could be net borrowers or lenders to other series. Serial associations were eventually supplemented (but not supplanted) by “non serial” associations starting as early as the 1860 s, which eliminated the grouping of members into series. ${ }^{8}$ Non serial associations gave each member his own series, avoiding the cash flow problems created by shares that matured all at once.

As a result of these changes, B\&L financial architecture was no longer inseparable from share accumulation loans. Terminating societies had required that all members eventually borrow, and in that context the share accumulation contract doubled as both a savings device and a repayment device. In contrast, at serial and non serial associations, borrowers did not need to have the same contract as savers. Nevertheless, for many years non-terminating B\&Ls retained share accumulation contracts for both parties. For savers, this was justified in part by the promotion of thrift. Share accumulation loans were also retained for borrowers as many preferred them to short term balloon loans offered by other lenders, and their risks remained dormant. In this way the share installment contract remained the customary feature of B\&L operations for both savers and borrowers.

\subsection{The introduction of amortized loans}

B\&Ls in Dayton, Ohio were the first nonfarm lenders in the country to adopt amortized loans, to the best of our knowledge. Such loans were introduced as part of a set of important innovations in $\mathrm{B} \& \mathrm{~L}$ operations that took place during the 1870 s and 1880s in Dayton. Over the next few decades Ohio B\&Ls in general became the national leaders in amortized lending. These associations also dropped the compulsory payment requirement for savers by introducing “optional” shares. Together, these two developments fundamentally shifted B\&L operations away from compulsory share installment contracts.

The so-called Dayton plan appears to have encompassed two different types of amortization for loans. One is the simple kind known as direct reduction, allowing "the borrower to apply directly on his notes that part of each loan payment not required for interest

\footnotetext{
${ }^{8}$ B\&L literature typically refers to these associations as "permanent" associations but we prefer the less-used "non serial" terminology as "permanent" conveys no information about the distinguishing features of the organizational plan used by these associations and falsely implies that serial associations terminated. Non serial was the term used in New Jersey and elsewhere.
} 
and advances for taxes, insurance, or assessments." ${ }^{9}$ The second form of amortization is a system known as "cancel and endorse." The cancel and endorse loan is a conceptual bridge between the old share accumulation loan and the direct reduction loan, and can be thought of as an intermediate step in the process of financial innovation. ${ }^{10}$ While a share accumulation contract required borrowers to purchase several shares that matured all at once, a cancel and endorse contract allowed borrowers to buy shares in succession. When each share reached maturity, the share would be "endorsed" over to the association and the principal debt "cancelled" by that amount, and the process repeated with the next share. This constituted a form of amortization, though more complicated than simply applying each loan payment directly to the principal debt. ${ }^{11}$

The existence of the cancel and endorse contract can be interpreted as some evidence that B\&Ls were reluctant to adopt direct reduction contracts not just because they eliminated the sharing of credit risk with borrowers but also because of the costs of other accounting and organizational changes. Fifty years later, an article in the Federal Home Loan Bank Review explicitly described this loan contract as a compromise between direct reduction and share accumulation that avoided some of the organizational changes needed for direct reduction loans. ${ }^{12}$ In economic terms, the cancel and endorse contract left the borrower with little of the risk inherent to sinking fund contracts, and therefore on a credit risk basis, it was almost identical to the direct reduction contract. However, in accounting and organizational terms, the differences were large enough that some B\&Ls opted for these contracts instead of direct reduction contracts, though this practice never gained the popularity of the other two contract types and faded by the 1940s.

The proximate source of these innovations appears to have been a visit to England by the manager of one Dayton association, A. A. Winters, who then implemented several new practices in imitation. True amortization in English building societies appears to date to at least as far back as the 1840s. ${ }^{13}$ Though these developments in Dayton were inspired by English practices,

\footnotetext{
${ }^{9}$ See Bodfish (1931) p. 95.

${ }^{10}$ Building and Loan Guide and Bulletin (1935) p. 110; Savings and Loan News (June 1935) p. 12; Federal Home Loan Bank Review (May 1935) p. 279.

${ }^{11}$ A.A. Winters described this method in Carroll (1894) p. 336, stating that under the Dayton plan, "A borrower may also, at any time, pay up one or more of his shares, and have the amount credited on his loan and interest stopped to that extent.” Whether this was the only form of amortization available at first is not clear.

${ }^{12}$ See the March, 1935 issue.

${ }^{13}$ Scratchley (1849) describes practices of some English societies at the time. A few decades before amortization
} 
the cost of adoption was lowered by fifty years of innovation in the American B\&L industry, as the Dayton plan also built on the American non serial plan. Much like the story of the 1930s adoption process, the story of adoption in Dayton during the 19th century has been simplified over the years. Writing in 1893, Winters described the Dayton plan as "not anybody's invention" but rather "the growth of twenty years." By 1938, though, the B\&L literature nevertheless credited the innovations to one man, Winters, "the guiding spirit of the association." By 1962, the B\&L literature describe the Dayton plan as simply "the work of a Dayton judge.”14 This sort of simplification is clearly tempting but ultimately obscures the complex nature of the innovation and adoption process.

\subsection{Costs of switching to direct reduction contracts}

Adopting the direct reduction contract involved three types of costs: the loss of credit risk sharing by borrowing members, the change in the mutual character of the association, and the implementation of changes to the association's accounting and organizational structure. In this section, we elaborate on each of these costs and discuss the methods developed by B\&Ls to cope with them. These costs were not prohibitively large, and a growing minority of associations overcame them before 1930, starting with the B\&Ls in Ohio in the 1880s. On the other hand, the benefits of adoption were also limited as long as borrowers had confidence in the share accumulation contract, which they did until the 1930s.

\section{$\underline{\text { Credit risk }}$}

The first cost relates to the allocation of credit risk. Under the share accumulation contract, a loan was paid off when the accumulated value of a borrower's share payments plus retained dividends reached the original amount of the loan. Until then, the borrower remained liable for the entire loan principal. If a B\&L suffered losses on its loan portfolio, its dividend rate could fall, which would increase the time it took borrowers to retire their loans because the

took hold in the United States, he clearly describes the risks of share accumulation loans: "Borrowers do not participate in any of the subsequent liabilities or expenses of the society, nor consequently in its profits.... The borrowers' repayments are for a fixed number of years, whatever is the subsequent condition of the society. This is one great improvement upon the old system, where the period of the subscriptions would depend on the future success or non-success of the association... so that in many cases the repayments are extended over several years more than was expected by a borrower when he first effected his loan” (p. 52-53).

${ }^{14}$ The quote from Winters was included on pages 333-337 of Carroll (1894). The "guiding spirit" quote is from Bodfish and Theobald (1938) p. 48. The "work of a Dayton judge” quote is from Ewalt (1962) p. 379. 
dividends would accrue at a slower rate. In more troubled cases, retained dividends could be taken away or the value of outstanding shares could actually be written down so that borrowers would see an absolute decrease in the sinking funds they had accumulated to pay off their loans. In all of these ways, borrowers shared credit risk under the share accumulation contract with non-borrowing members of the association. Under direct reduction, in contrast, the principal of a loan was extinguished dollar-for-dollar with the borrower's payment each month so that the effective loan balance was not influenced by the association's earnings. As a result, borrowers bore none of the association's credit risk.

In traditional B\&Ls, savers (non-borrowing members) also used share accumulation contracts to invest in the B\&L, so they were exposed to the same credit risk as borrowers. Though we focus on loan contracts in this paper, much innovation within B\&Ls before 1930 was designed to reduce the risks to savers in order to offer a more competitive savings vehicle. These innovations became useful for associations seeking to adopt direct reduction loans, as they gave mechanisms for handling credit risk that would no longer be partly borne by borrowers. In Ohio, innovation to deal with credit risk took the form of loss reserves that smoothed credit losses over time. To create these reserves, Ohio B\&Ls diverted earnings by funding their operations partly with deposit liabilities that yielded low returns but carried little risk. Deposits accounted for about half of Ohio B\&L funding by 1930, far more than in any other state. Bodfish (1931, p. 98) describes these “contingent” reserves as becoming more prevalent between 1890 and 1900, and reserves became mandated by state law. In addition, state law also required that if an Ohio B\&L accepted deposits, its shareholders then assumed double liability for any potential losses (i.e. they could lose their investments and were liable for an assessment equal to the face value of their investments).

Loss reserves were also developed in New York during the early 1900s. Their importance was noted during the 1930s when the adoption of direct reduction loans was being discussed. A New York B\&L official described loss reserves as a key accompaniment to amortization: "In my own state of New York a number of our associations have successfully used the loan plan for 15 years or more... To those who might object to the use of the direct reduction plan because the borrowing member will never participate in the losses of the associations, I have only one answer. A properly conducted building and loan association is able to absorb all its losses through it reserves which have been built up out of the profits of the 
association for that purpose.” ${ }^{15}$ This makes clear that B\&L leaders viewed loss reserves as connected to lending practices.

In California, innovation took the form of "investment certificates"-liabilities similar to modern certificates of deposits, with guaranteed dividends and no compulsory installment obligations - which accounted for 71 percent of California B\&L liabilities by 1929. As was the case with Ohio's deposits, some others in the B\&L industry denounced the non-mutual nature of such liabilities, as savers did not share in any credit risk. Nevertheless, they successfully attracted large amounts of funding. These liabilities were made possible by the addition of nonwithdrawable capital stock, which functioned much like capital at commercial bank. This capital was generally held by the directors of an association and created an alternate buffer against credit risk for other classes of liabilities that enjoyed definite interest rates. This innovation allowed California B\&Ls to offer borrowers a contract with less credit risk: borrowers bought shares, but those shares had guaranteed rates of return, as the new classes of capital provided a buffer ${ }^{16}$

Adopting such methods for dealing with credit risk lowered the cost of adopting direct reduction contracts but did not necessarily lead to such adoption. For example, Kansas B\&Ls developed non-withdrawable capital stock similar to California B\&Ls, and a scattering of B\&Ls across the country recognized the prudence of loss reserves, but these institutions did not always adopt amortized loans too.

\section{Mutuality}

The second cost of adopting direct reduction loans relates to mutuality. Share accumulation contracts ensured that borrowers owned shares and therefore were members. Mutuality, defined in this manner, was responsible for the exemption of B\&Ls from taxation, particularly federal taxation. The US Building and Loan League, a key trade association, successfully pushed for an exemption from federal taxation for B\&Ls on these grounds in the Wilson Tariff Act of 1894, which established the first peacetime income tax. ${ }^{17}$ While the income tax as established by that Act was soon declared unconstitutional, it established a

\footnotetext{
${ }^{15}$ C. Harry Miniers, “The Direct Reduction Type of Mortgage,” US Building and Loan Annals (1934) p. 295.

${ }^{16}$ See Bodfish (1931), History of California B\&Ls, p. 320. Both investment certificates and direct reduction loans gained favor around the same time, between 1895 and 1910.

${ }_{17}$ The first exemption for B\&Ls from federal taxation was included in the Wilson Tariff Act at the urging of the Ohio Building and Loan League. Bodfish (1931, Ch. XIII) provides a comprehensive history of the industry's extensive efforts to obtain and then keep the exemption. See also Chase and Clark (1925, Ch. XXII) and Riegel and Doubman (1927, Ch. XII).
} 
precedent, repeated in a variety of federal corporate and individual tax provisions before 1930, in which exemptions were granted to "building and loan associations which make loans only to their shareholders." 18 Because the direct reduction loan contract did not require that borrowers purchase shares to repay their loans, B\&Ls that adopted it had to find ways to maintain the exemption by addressing what could be perceived as a loss of mutuality. The most common tactic involved requiring borrowers to purchase nominal amounts of membership shares, such as special shares with maturity value of $\$ 1$ and no further payment requirements. Cancel and endorse contracts were also a potential method to deliver amortization while still requiring purchase of shares. In this way borrowers were still technically members and therefore the associations retained mutuality according to the legal definition for tax purposes.

It is doubtful that tax authorities were fooled by these tactics, but it appears they accepted such practices for many years. This is the sort of practical knowledge on the part of B\&Ls that was critical to supporting the rapid pace of adoption during the 1930s. Associations that had doubts about mutuality were informed of these tactics by others from Ohio or New York, who could speak of their success from experience. ${ }^{19}$

\section{$\underline{\text { Accounting and organizational costs }}$}

The final set of adoption costs is a broad set of accounting and organizational changes that were required when switching loan contracts. To begin with, direct reduction contracts required an accounting system based on individual accounts so that payments on each loan could be tracked separately. Such individual ledger books had not been necessary under the share accumulation loan contract where B\&Ls tracked only payments on shares, and not loan payments. These changes were likely more difficult for serial associations that still used grouped share accounts than for non-serial and Dayton associations. For example, in a non-serial or Dayton association, an existing borrower could have his loan converted to a direct reduction loan, without affecting the individual accounts of all the other members. B\&L managers also needed to learn the mechanics of administering an amortized loan. For example, it was important for managers to know how much of a borrower's monthly payment would be applied

\footnotetext{
${ }^{18}$ See Studenski and Kroos, pp. 220-222, for the constitutional issues associated with the Wilson Tariff Act.

${ }^{19}$ See Bodfish (1927) and the Building and Loan Annals (1934) p. 296, and the Building and Loan Guide and Bulletin (1935) p. 111, for discussion of how existing users of direct reduction loans dealt with mutuality concerns, and how they disseminated this information to others during the 1930s.
} 
to interest or principal in any given month, and what monthly payment would retire a loan over a certain period of time. The process of refinancing existing loans required some instruction. ${ }^{20}$ Finally, in terms of organizational costs, changes in the structure of loan contracts usually also required modification of $B \& L$ bylaws by membership vote, which were often subject to the approval of supervisory authorities. ${ }^{21}$

During the 1930s, B\&L officers learned the mechanics of the direct reduction loans through an extensive educational campaign conducted by B\&L trade associations and the federal government. Beginning around 1934, the major trade magazines and government journals all published amortization tables that B\&L officers could use as references, invaluable in a world before digital computers. Also published were simple guides such as the size of a monthly

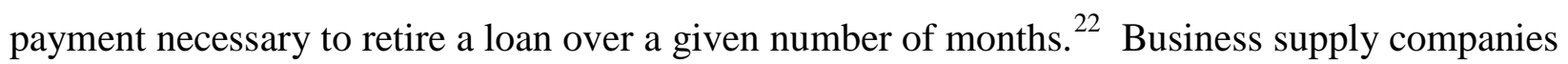
also began to widely sell accounting books and calculating machines designed for direct reduction contracts.

Trade groups also developed courses of instruction on new accounting techniques. ${ }^{23}$ Such courses disseminated new legal language for mortgage forms and association by-laws, examples of passbooks that could be issued to borrowers and would track payments on principal and interest, and reveal the balance due at any given time. Through these efforts, B\&L officers learned what entries were required in their associations' ledgers and cash books, how to recast old share accumulation mortgages into direct reduction mortgages, and how to handle delinquencies with these new contracts. Naturally, business supply companies began to advertise new products, such as standardized passbooks for borrowers and accounting forms and accounting machines for associations. ${ }^{24}$ Importantly, these efforts were based on fifty years of experience with direct reduction contracts. This experience meant that adopting direct reduction loans was a matter of disseminating techniques for their use rather than inventing them anew.

The magnitude of these accounting and organizational costs should not be overstated, yet these issues do relate to the core of financial innovation. The direct reduction contract

\footnotetext{
${ }^{20}$ An article in the Savings and Loan News (May 1935) p. 15, describes the process and offers a legal conversion agreement template.

${ }^{21}$ For example, see Building and Loan Annals, 1937 p. 325.

22 See American Building Association News, August 1934, p. 364 and September 1938 p. 409; Building and Loan Guide and Bulletin, 1935 p. 7 and p. 108; Federal Home Loan Bank Review, March 1935, p. 189

${ }^{23}$ Ewalt (1962), p. 152.

24 American Building Association News, September 1935 p. 433, October 1935 p. 466 and Nov 1935 p. 524 ; Savings and Loan News, February 1933, p. 7, May 1934, p. 14, and October 1935 p.3; Building and Loan Guide and Bulletin 1935 p. 7 and p. 111; United States Building and Loan Annals, 1934 p. 298.
} 
innovation boils down to a set of organizational procedures and accounting forms and practices. Though the practices required to implement such loans may seem obvious in retrospect, the extensive educational campaign during the 1930s suggests otherwise.

\subsection{The extent of amortization in the 1890s}

The first data that comprehensively record the use of amortization at B\&Ls come from the extraordinary 1893 report of the Commissioner of Labor (Wright 1893), the first complete census of the nation's B\&Ls. ${ }^{25}$ Among other tabulations, the report gives the number of associations in each state that allowed for periodic reductions in principal debt. Though the data do not distinguish whether the periodic reductions are accomplished through direct reduction or cancel and endorse arrangements, the evidence shown in Table 1 provides a valuable look at the use of contracts at the time.

Table 1: The spread of amortization by 1893

\begin{tabular}{lcc}
\hline \hline & $\begin{array}{c}\text { Number of } \\
\text { associations using } \\
\text { amortization }^{\mathrm{a}}\end{array}$ & $\begin{array}{c}\text { Total number } \\
\text { of } \\
\text { associations }\end{array}$ \\
\hline Ohio & 254 & 718 \\
Maryland & 63 & 237 \\
New Jersey & 24 & 286 \\
Pennsylvania & 64 & 1076 \\
District of Columbia & 1 & 26 \\
Indiana & 1 & 429 \\
Minnesota & 2 & 82 \\
Missouri & 1 & 349 \\
Wisconsin & 1 & 39 \\
Rest of the country & 0 & 2596 \\
\hline Total & 411 & 5838 \\
\hline \hline Amortization refers to the use of either direct & reduction or \\
cancel-and-endorse loans & &
\end{tabular}

In general, the share accumulation plan was the dominant loan form. Out of 5,838 B\&Ls in the country, 5,427 (93 percent) did not use amortization. The report summarized typical practices this way: "Dues and interest are usually paid periodically... As a rule, the plans of the

\footnotetext{
${ }^{25}$ As far as we know, the next census was not until the 1935 Census of Business.
} 
associations provide that loans on real estate shall run to the maturity of the shares pledged, the maturing value of the shares being equal to the loan and by maturity satisfying the loan. In some associations, however, the loans run for a fixed period” (p. 387). Such fixed period loans are only possible through the elimination of credit risk for borrowers.

Table 1 details the number of associations in each state that reported the use of amortization. Only in two states, Maryland and Ohio, did a large fraction of active B\&Ls report amortization. In both Ohio and Maryland the 1893 report describes associations as using plans in which "principal is reduced periodically by the amount of dues paid in, and interest is charged on the balance only." In no other state was amortization as widespread: New Jersey, Pennsylvania reported moderate use of some amortization, and 6 associations scattered across the District of Columbia, Indiana, Minnesota, and Missouri reported amortization as well.

The exceptionalism of Ohio is consistent with the development of the Dayton plan in that state, as noted above. Unfortunately, much of the early history of Maryland associations remains unknown, as the state lacked supervision for B\&Ls until the 1940s. As a result, it is difficult to know how Maryland associations dealt with the costs of adopting direct reduction loans. The 1868 Maryland laws of incorporation allowed for what was essentially a direct reduction plan, but for reasons that are not fully apparent this development never proved as influential as the developments in Ohio (Bodfish and Theobald 1931, p. 49). We simply interpret the parallel developments in Ohio and Maryland as part and parcel with the innovation process that characterized the industry during these years, in which new financial features were constantly developed and even developed more than once.

\subsection{The state of amortization in the 1920s}

Data on the use of direct reduction contracts in the 1920s are limited. Virtually all studies that discuss loan contracts during the 1920s and 1930s cite the same data set, which was constructed by the NBER in 1947. In that year, the NBER surveyed building/savings and loan associations, as well as commercial banks and life insurance companies, with requests for samples of loans that had been originated between 1920 and 1947. The savings and loan sample consists of about 4700 loans made by 92 savings and loan associations. ${ }^{26}$

\footnotetext{
${ }^{26}$ Scans of the original data are available at the NBER website: http://www.nber.org/nberhistory/historicalarchives/. Morton (1956) contains a description of the sampling process in Appendix A, as well as a discussion of the biases. The Morton volume discusses all of the financial surveys, while Behrens (1952) focuses on commercial banks, and
} 
In the next section, we present higher quality data on the 1930s from a different source, but we have yet to find any better sources for the 1920s. Though the NBER data are unique and quite valuable, they are also subject to substantial bias. To begin with, there is likely to be a strong survivorship bias in the sample for the 1920s because one-third of the more than 12,000 operating B\&Ls in 1929 failed during the 1930s. Moreover, nonresponse bias also appears to be problematic, since the NBER asked 500 B\&Ls to respond but received responses from only 92.

Despite these problems, Table 2 reports the information given by the NBER data on loan plans, among B\&Ls. To the best of our knowledge, these data have not been summarized publicly in this fashion before. ${ }^{27}$

Table 2: NBER Data on Loan Contracts

\begin{tabular}{lccccc}
\hline \hline & $1920-$ & $1930-$ & $1935-$ & $1942-$ & $1946-$ \\
Contract Type & 1929 & 1934 & 1941 & 1945 & 1947 \\
\hline Share accumulation & 46.7 & 54.1 & 13.9 & 5.0 & 5.4 \\
Cancel and Endorse & 12.2 & 5.6 & 2.7 & 1.2 & 1.1 \\
Direct Reduction (non-FHA/VA) & 35.3 & 34.2 & 76.8 & 85.5 & 61.7 \\
Direct Reduction (FHA/VA) & 0.0 & 0.2 & 4.9 & 7.1 & 31.3 \\
Straight & 5.6 & 5.9 & 0.2 & 0.1 & 0.3 \\
Contract N/A & 0.2 & 0.0 & 1.5 & 1.1 & 0.2 \\
\hline \hline
\end{tabular}

Notes: This tabulation is taken from Table 17 of a preliminary and ultimately unpublished NBER manuscript dated to December 1950, by Edward E. Edwards, titled Urban Real Estate Financing by Savings and Loan Associations.

It is available from the authors.

Table 2 indicates that, among the S\&Ls surveyed, 35 percent of loans originated between 1920 and 1929 were direct reduction loans, while only 47 percent were share accumulation loans. We suspect the estimated use of direct reduction contracts is too high, biased upwards by perhaps about 10-15 percentage points. As a benchmark, suppose that 90 percent of Ohio associations used direct reduction loans in the 1920s, as did half of California and New York associations (as indicated by historical sources discussed more below), and perhaps most of Maryland. Given the geographic distribution of the B\&L assets in 1930, (shown in a table given in the appendix), this would imply about 20 percent of loans at the time were direct reduction loans. The number might be a bit higher given small penetration in other states, but it is difficult

Saulnier (1950) focuses on life insurances companies. The S\&L sample was intended for publication in an analogous volume authored Edward Edwards, but the volume was never published.

${ }^{27}$ The tabulation for B\&Ls and S\&Ls was assembled for a preliminary version of an NBER volume on the loan experience of savings and loan associations, but the volume was never published, perhaps because of the concerns we outline here. 
under any plausible assumptions to reach a number such as 35 percent.

Indeed, the NBER sample was quite skewed geographically. Ohio and New Jersey should be equally represented in the sample; each accounted for about 14 percent of national B\&L loans in 1930. However, Ohio - the nation's bastion of direct reduction lending in the 1920s - accounts for 19 percent of the sample, while New Jersey - a state wholly devoted to traditional share accumulation lending - accounts for only 2 percent. Similarly, Pennsylvania is also dramatically underrepresented, and Philadelphia, the city that had the most B\&Ls in the country in 1930, is entirely unrepresented. Of course, these biases are not surprising given the enormous number of lenders that liquidated in the mid-Atlantic area during the 1930s.

Although we do not place much faith in the aggregate implications of the NBER sample, it does give a useful general measure of the geographic extent of diffusion. Consistent with what we know about the structure of the industry, twelve of fifteen Ohio B\&Ls in the sample reported use of direct reduction loans in the 1920s, and the other three were split between cancel and endorse and share accumulation loans. Seven of eight Californian B\&Ls used direct reduction loans as well, along with the only lender in Maryland, half of those sampled in New York, and a few others in Washington and Michigan. All the remaining associations used cancel and endorse or share accumulation contracts.

\section{The 1930s transition}

Up to this point, we have established that the direct reduction contract was well known in the B\&L industry before 1930, but we have not yet characterized the adoption process during the 1930s. In this section we use two sources of data to describe that process. First, we use quantitative data from the annual reports of thousands of B\&Ls located in sixteen states to show that the adoption of direct reduction contracts abruptly accelerated in the mid-1930s. Second, we collect a variety of qualitative data in other states that capture the same basic pattern in most of those states, with the exceptions being states in which direct reduction lending had already become widely used before 1930. We begin, though, with a brief case study of B\&Ls in Iowa, in order to introduce the type of data we have collected, and to preview the pattern of adoption over time. 


\subsection{Transition in Iowa}

Annual reports on the condition of state-chartered B\&Ls in Iowa directly measure of how B\&L loan plans changed during the 1930s in that state. These reports indicate which of three loan plans-direct reduction, share accumulation, or cancel and endorse-was used by each association for new loan originations in each year starting in 1935. Iowa also reports the stock of direct reduction loans held at the end of each year, which is the measure available for most other states that we use in the next subsection. Therefore, Iowa's B\&Ls have a uniquely valuable set of records regarding the stock and flow of direct reduction loans.

As background, there were 59 state-chartered B\&Ls active in Iowa in 1935. In 1940, this number remained 59, reflecting 10 new state-chartered associations that offset the loss of 10 existing associations (through 5 liquidations, 1 federalization, and 4 mergers). ${ }^{28}$ At the federal level, 32 additional associations were active in 1940. Almost all of these federal associations had been organized in 1933 or 1934 as part of a federal effort to target geographic areas not served by any state-chartered association. Compared to other states this is a relatively small number of B\&Ls, limited to Iowa's cities and towns, creating a simple setting that permits an uncomplicated examination of loan contracts within a homogenous regulatory environment.

Table 3 reports the number of state-chartered B\&Ls that used the different types of loan contracts for each year beginning in 1935. Direct reduction contracts first became used in that year; writing in 1935, the state regulator observed that "[u]ntil last year or so all of our associations have made loans on what is commonly known as the Share Accumulation Plan.” The transition in Iowa, therefore, appears to have begun in 1935 when 4 state-chartered associations reported using the direct reduction loan plan. From that point the adoption spread rapidly so that 41 of 59 state associations reported its use in 1940. Ten of these were newly formed associations which adopted direct reduction loans from the outset. In Iowa, therefore, 31 of the 49 B\&Ls that were active at the beginning of 1935 and extant in 1940 changed their loan plans to direct reduction during the intervening five years.

${ }^{28}$ One additional state chartered association was formed after 1935 but then federalized before 1940. 
Table 3: Adoption of direct reduction loans in Iowa

\begin{tabular}{|c|c|c|c|c|c|c|c|}
\hline \multirow[b]{2}{*}{ Year } & \multicolumn{6}{|c|}{$\underline{\text { State-chartered associations }}$} & \multirow[b]{2}{*}{$\begin{array}{l}\text { Federally } \\
\text { chartered } \\
\text { associations } \\
\text { (all using } \\
\text { direct } \\
\text { reduction) }\end{array}$} \\
\hline & \multicolumn{2}{|c|}{\begin{tabular}{|cc} 
All associations \\
& Number \\
& using \\
Number & direct \\
active & reduction
\end{tabular}} & $\begin{array}{c}\text { Number } \\
\text { active }\end{array}$ & $\begin{array}{c}\text { Number } \\
\text { using } \\
\text { direct } \\
\text { reduction }\end{array}$ & $\begin{array}{c}\text { Number } \\
\text { adopting } \\
\text { direct } \\
\text { reduction }\end{array}$ & $\begin{array}{l}1935 \\
\text { Number } \\
\text { adopting } \\
\text { cancel } \\
\text { and } \\
\text { endorse }\end{array}$ & \\
\hline 1935 & 59 & 4 & 59 & 4 & 4 & 9 & 32 \\
\hline 1936 & 60 & 16 & 56 & 12 & 10 & 3 & 32 \\
\hline 1937 & 60 & 24 & 54 & 18 & 8 & 1 & 32 \\
\hline 1938 & 61 & 36 & 51 & 26 & 9 & 2 & 31 \\
\hline 1939 & 60 & 38 & 50 & 28 & 3 & 2 & 32 \\
\hline 1940 & 59 & 41 & 49 & 31 & 4 & 0 & 32 \\
\hline
\end{tabular}

In the first part of the paper, we noted that organizational and accounting costs were one factor affecting the adoption calculus regarding direct reduction contracts. In the context of Iowa, these costs manifest in the data regarding the usage of serial or non-serial operating plans (not shown in Table 3). In fact, the adoption of the direct reduction loan plan by Iowa B\&Ls was in every case accompanied or preceded by conversion to the non-serial plan if an association was previously organized under the serial plan. In most cases these two changes were put in place during the same year. ${ }^{29}$ Moreover, most of the associations operating on non-serial plans in 1935 that adopted direct reduction loans did so by the end of 1937, whereas most serial associations as of 1935 were slower to adopt, doing so after 1937. Table 3 also indicates that 17 associations adopted cancel and endorse contracts at some point between 1935 and 1939, but that by 1940 this compromise solution (used by serial associations to approximate a true direct reduction contract) had completely disappeared. In explaining these developments, there is no indication that state law required organizational conversions to accompany any of these changes in loan contracts, so the Iowa evidence appears to underscore that the adoption of direct

\footnotetext{
${ }^{29}$ Of the 59 associations that existed in 1935, 38 adopted direct reduction contracts at some point between 1935 and 1940 (although not all of these were still active by 1940). 27 were already operating on the non-serial plan in 1935 and therefore did not change their organizational plan. The other 11 associations were operating on the serial plan in 1935, and every one of these 11 converted to non-serial associations. In 8 cases, the organizational change occurred in the same year as the loan plan change, and in the other 3 cases, the organizational change occurred one or two years earlier.
} 
reduction lending involved additional and costly organizational changes. This indicates that the broad accounting and organizational changes required by direct reduction contracts induced Iowa B\&Ls to change their fundamental plans of operation in the course of adoption.

\subsection{Transition in a panel of states}

Beginning in the mid-1930s, B\&L regulators in 16 states (including Iowa) published information about the use of direct reduction contracts in their annual reports. (See the data appendix for a listing of these annual reports.) In Table 4, we present aggregate state-level statistics for all state-chartered B\&Ls in those states, covering each year from 1935 to 1945 . In Table 5, we combine this information with statistics on federally-chartered S\&Ls in each state, published in annual reports by the Federal Home Loan Bank Board. In both tables, each cell represents the share of outstanding loans (by value) that were direct reduction loans for a given state in a given year. Therefore, these data measure changes in the composition of the stock of loans held by B\&Ls, in contrast to the NBER data, which measure changes in the composition of new originations, and the Iowa data in Table 3, which record the plan used for new originations in each year. ${ }^{30}$

Table 4 makes clear that the pace of adoption among state-chartered B\&Ls was rapid. In 1935, use of direct reduction loans was very limited. By the next year, such loans had made rapid inroads into several states, and by 1940 in most states more than 40 percent of outstanding loans were of the direct reduction form. By 1945, adoption was nearly complete in many states. Therefore, over a ten year period, there was an almost total abandonment of the 100-year old share accumulation contract. No existing data make the pace of the transition so clear.

In Iowa, for example, nearly two-thirds of outstanding loans held by state-chartered associations were direct reduction loans by 1940, even though the contract was first used in that state just five years earlier. Illinois and New Jersey B\&Ls also exhibit particularly rapid adoption, with direct reduction loans accounting for very little in 1935 but for more than 50 percent of all loans in 1940. In five states, the direct reduction share in 1940 exceeded twothirds, though in one state, New York, it appears that such loans had made inroads before 1935.

The fact that several observations for 1935 are missing in Table 4 likely reflects low use

\footnotetext{
${ }^{30}$ B\&Ls were portfolio lenders, and engaged in very little secondary market activity. Therefore, new originations were generally retained.
} 
of direct reduction contracts, as those states' regulators did not yet consider it important enough to report such information. For example, in Illinois, direct reduction loans were only made legal in July, 1935, and the state regulator noted in the 1936 report that the number of such loans had been too few at year-end 1935 to justify the trouble of tabulating and reporting them. ${ }^{31}$

Table 4: Direct reduction loans as a percent of all loans, state-chartered B\&Ls

\begin{tabular}{lrrrrrrrrrrr}
\hline \hline State & $\mathbf{1 9 3 5}$ & $\mathbf{1 9 3 6}$ & $\mathbf{1 9 3 7}$ & $\mathbf{1 9 3 8}$ & $\mathbf{1 9 3 9}$ & $\mathbf{1 9 4 0}$ & $\mathbf{1 9 4 1}$ & $\mathbf{1 9 4 2}$ & $\mathbf{1 9 4 3}$ & $\mathbf{1 9 4 4}$ & $\mathbf{1 9 4 5}$ \\
\hline $\mathrm{CT}$ & & 6.4 & 14.3 & 21.4 & 30.0 & 40.0 & 49.2 & 54.1 & & & \\
MA & 0.5 & 4.6 & 11.4 & 17.6 & 23.8 & 31.7 & 41.0 & 47.7 & 52.6 & 56.5 & 62.4 \\
ME & & & & & & & 56.6 & 63.2 & 66.8 & 74.9 & 76.4 \\
NH & 0.0 & 4.2 & 10.7 & 17.8 & 22.0 & 27.7 & 31.6 & 34.8 & 36.6 & 38.8 & 44.8 \\
VT & & & & & 40.7 & 49.2 & 33.1 & 40.3 & 43.7 & 51.2 & 48.1 \\
& & & & & & & & & & & \\
NJ & 6.5 & 10.2 & 13.3 & 18.1 & 40.7 & 51.5 & 59.8 & 65.6 & 70.1 & 75.5 & 80.1 \\
NY & & 47.9 & 48.7 & 55.5 & 61.7 & 67.6 & 73.8 & 77.0 & & 82.5 & 86.4 \\
& & & & & & & & & & & \\
IL & & 15.8 & 21.8 & 33.4 & 44.0 & 57.8 & 68.2 & 73.7 & 78.2 & 83.1 & 87.5 \\
IN & & 39.6 & 49.1 & 55.6 & 62.2 & 68.6 & 69.5 & 69.5 & 77.1 & 79.9 & \\
WI & 14.8 & 30.0 & 41.7 & 47.0 & & 67.9 & 71.5 & 75.1 & 82.8 & 89.1 & \\
IA & 1.8 & 21.5 & 42.8 & 52.8 & 58.8 & 65.9 & 64.3 & 75.4 & 77.8 & 78.3 & 80.4 \\
KS & 25.7 & 40.6 & 47.1 & 59.0 & 58.1 & 64.7 & 65.5 & 69.7 & 71.4 & 76.2 & 81.7 \\
NE & 12.7 & 47.1 & 49.2 & & 56.3 & 61.0 & 62.9 & 66.7 & 68.1 & 69.0 & 78.5 \\
& & & & & & & & & & & \\
LA & 4.2 & 24.8 & 56.4 & 69.7 & 79.5 & 84.8 & 88.3 & 90.3 & 92.5 & 94.4 & 94.7 \\
TX & & 66.0 & 76.2 & 81.8 & & & 91.5 & 93.2 & 95.4 & 97.2 & 98.2 \\
VA & & 26.5 & 30.2 & 35.0 & 42.7 & 45.0 & 54.8 & 60.9 & 66.2 & 70.6 & 77.9 \\
\hline \hline
\end{tabular}

Notes: See the appendix for the data sources. Empty cells indicate that the publications could not be located for those state-years (due either to non-publication or rarity) and data could not be estimated either. Data for a few cells are estimates based on items from the liability side of B\&L balance sheets. Since share accumulation loans involve pledging shares, the amount of these shares can be used to estimate the amount of share accumulation loans if such shares are specified as separate liability items. Such estimation requires an assumption regarding the ratio of outstanding share accumulation loans (on the asset side) to pledged shares (on the liability side); such ratios are fairly constant within states over a few years. The estimated cells are Iowa in 1935, Illinois in 1936, Texas in 1944 and 1945, New York in 1936, Indiana after 1936, and Nebraska in 1935-1937, 1942, and 1945.

Turning to Table 5, which includes both state- and federally-chartered B\&Ls, a similar but stronger pattern emerges. Because all federally chartered B\&Ls were eventually required to use direct reduction loans, the numbers in Table 5 are necessarily larger in each state-year than in

\footnotetext{
${ }^{31} 1936$ Illinois annual report, p. IX.
} 
Table $4{ }^{32}$ Comparing Table 5 with Table 4 also reveals that the new federal savings and loan associations had substantial presence in the market in several states by 1936-most prominently Connecticut, New Hampshire, New York, Indiana and Kansas. Though federal charters were first available only in 1933, they quickly attracted the conversion of many state-chartered B\&Ls in these states.

Table 5: Direct reduction loans as a percent of all loans, federal- and state-chartered B\&Ls

\begin{tabular}{|c|c|c|c|c|c|c|c|c|c|c|c|}
\hline State & 1935 & 1936 & 1937 & 1938 & 1939 & 1940 & 1941 & 1942 & 1943 & 1944 & 1945 \\
\hline CT & & 24.0 & 37.1 & 45.7 & 54.7 & 64.7 & 74.0 & 77.9 & & & \\
\hline MA & & 6.0 & 26.5 & 33.6 & 40.0 & 48.0 & 56.1 & 61.1 & 65.1 & & \\
\hline $\mathrm{ME}$ & & & & & & & 59.2 & 65.5 & 69.1 & 77.0 & 78.8 \\
\hline NH & & 33.0 & 40.7 & 46.7 & 50.8 & 56.6 & 59.9 & 60.9 & 60.9 & 61.8 & 65.9 \\
\hline VT & & & & & 62.9 & 75.3 & 75.0 & 77.1 & 79.5 & 82.8 & 81.7 \\
\hline NJ & & 10.2 & 13.3 & 18.1 & 41.3 & 52.5 & 61.3 & 67.0 & 70.1 & 75.5 & 80.6 \\
\hline NY & & 69.7 & 65.7 & 71.4 & 77.1 & 81.2 & 85.5 & 87.0 & & 90.8 & 93.1 \\
\hline IL & & 32.1 & 44.4 & 55.9 & 65.5 & 75.8 & 82.1 & 84.8 & 87.7 & 91.9 & 93.5 \\
\hline IN & & 68.5 & 75.5 & 78.6 & 82.2 & 85.4 & 85.9 & 86.0 & 89.7 & 91.1 & \\
\hline WI & & 33.2 & 46.2 & 52.3 & & 74.9 & 78.2 & 81.3 & 87.2 & 92.3 & \\
\hline IA & & 34.9 & 56.1 & 65.7 & 72.7 & 78.6 & 78.3 & 85.4 & 87.4 & 88.2 & 89.3 \\
\hline KS & & 46.6 & 55.9 & 70.0 & 74.8 & 79.8 & 79.2 & 82.2 & 84.4 & 89.4 & 90.6 \\
\hline $\mathrm{NE}$ & & 50.8 & 54.1 & & 62.0 & 66.8 & 68.9 & 72.1 & 73.5 & 74.6 & 82.4 \\
\hline LA & & 35.6 & 63.0 & 74.6 & 82.9 & 87.3 & 90.1 & 91.8 & 93.6 & 95.2 & 95.5 \\
\hline TX & & 76.0 & 84.2 & 90.5 & & & 96.6 & 97.1 & 98.0 & 98.7 & 99.2 \\
\hline VA & & 43.1 & 53.1 & 58.6 & 67.3 & 70.3 & 76.2 & 79.9 & 83.4 & 86.6 & 90.5 \\
\hline
\end{tabular}

Notes: See the notes to the previous table as well. Data from 1935 are not included because no federal S\&L data were published that year.

Because the data in Tables 4 and 5 measure loan stocks, they show a smoother and longer transition than would be measured by data on loan originations. The Iowa annual reports, which give data both on stocks and flows, are particularly helpful in this regard. In terms of flows, we have seen in Table 3 that the number of state-chartered associations originating direct reduction

\footnotetext{
${ }^{32}$ The requirement was gradually imposed between 1933 and 1936, as we will explain in section 5 .
} 
loans in the state increased most rapidly between 1935 and 1938 and then grew much more slowly. In terms of stocks, the Iowa data in Table 4 shows a very similar pattern, with rapid increases between 1935 and 1938 and a more gradual increase after that date. For at least one state, therefore, the transition looks quite similar whether measured by changes in loan origination practice or loans outstanding.

The data in Tables 4 and 5 also reflect conversions of old share accumulation loans into direct reduction loans. The Iowa pattern is consistent with this practice, and there is evidence that it was widespread during the 1930s. For example, New York regulators reported "The advantages of this type of mortgage have also been extended to a considerable number of previous borrowers through conversion of their loans to the direct reduction plan." On a more national basis, the Federal Home Loan Bank Review stated that "it is common knowledge that these transfers were substantial." ${ }^{33}$ In New Jersey, recasting of loans was linked to a comprehensive federally-led effort to salvage the state's B\&Ls in the late 1930s. Though recasting of loans was not generally required for insurance through the Federal Savings and Loan Insurance Corporation, federal officials chose to require such recasting when offering the type of comprehensive salvaging operations that occurred in places like Newark, New Jersey (See Rose 2011). As a benchmark in assessing the importance of conversions, suppose that an association retained all the existing share accumulation loans on its books but wrote all new loans as direct reduction contracts. The transition process, as measured by stocks, would take about 12 years, since that is the amount of time required for typical share accumulation loans to run off. The fact that the transition process appears to be faster than 12 years in most states years likely reflects that it was common for existing loans to be converted to direct reduction loans when the contract was first adopted.

We can also compare the data in Tables 4 and 5 to the NBER data in Table 3. The NBER data give only a general sense of the transition to direct reduction loans during the 1930s, as the statistics are grouped in five year intervals. Direct reduction loans become much more common in the sample after 1935, accounting for over 80 percent of originations in the second half of the 1930s, and an even larger percentage in the 1940s. The NBER data also indicate that new originations of share accumulation contracts declined considerably after 1935, to only about 5

\footnotetext{
${ }^{33} 1940$ New York annual report, p. 7; Building and Loan Guide and Bulletin, Feb. 1938, p. 22; FHLBR April 1942, p. 231.
} 
percent of all originations by the 1940s. More refined year-to-year statistics are not readily available, as the complete NBER sample would have to be digitized, and year-by-year statistics would probably be of dubious worth given the sample size and biases. In fact, compared to the NBER data, our data have the considerable advantage of covering every B\&L in operation at the time in these states and so do not suffer from similar survivor or nonresponse biases.

Compared to the NBER data, the changes in this state-level panel after 1935 appear even more drastic, as there is little indication that these states had used direct reduction loans pre-1935 to the extent suggested by the NBER data. This is partly a function of the omission of Ohio and California, two states with the most widespread use of direct reduction loans before the Depression. We need to address, therefore, how the omission of these and other states could influence the course of transition to direct reduction as shown in Tables 4 and 5.

\subsection{States not included in Tables 4 and 5}

Though Tables 4 and 5 cover only 16 states, these 16 states accounted for a large portion of the nation's B\&L loans. In 1930, B\&Ls in these states held 48 percent of loans held by all B\&Ls in the country (see the table in the Appendix). ${ }^{34}$ In addition, B\&Ls in Ohio accounted for another 14 percent, and as noted above, it is well established from contemporary sources that direct reduction loans were widely used in Ohio prior to the Depression. Our own estimates suggest that over $90 \%$ of Ohio loans were direct reduction loans throughout the 1930 s. $^{35}$ Therefore, we are able to characterize the adoption rate for states that held 62 percent of the nation’s B\&L loans in 1930.

The remaining states not listed in Table 4 or 5 accounted for 38 percent of B\&L loans in 1930. ${ }^{36}$ Among these states, a group of only eight accounted for the bulk, holding 30 percent of national B\&L loans. These states either did not publish any publicly available reports on B\&Ls

\footnotetext{
${ }^{34}$ Source for this paragraph: p. 377 of the 1932 Building and Loan Annals.

35 This estimate is based off of the amount of shares on the liability side of Ohio B\&L balance sheets that are pledged toward mortgage loans. For example, in 1935 there are \$10.7 million in pledged shares and \$461.4 million in outstanding loan. Typically in data from other states, pledged shares support about 3-4 times their value in mortgage loans, implying about $\$ 42.8$ million in share accumulation loans, leaving more than 90 percent of the $\$ 461.4$ million loans as direct reduction loans.

${ }^{36}$ Of the other 32 states that are not listed in Table 5 (excluding the territories of Alaska and Hawaii), 21 did not distinguish between loan plans. We have not been able to locate annual reports for the other 11 in this period, likely because no reports were published. These states without reports are Arizona, Arkansas, Maryland, Minnesota, Mississippi, New Mexico, Oklahoma, Pennsylvania, South Carolina, and Wyoming. We have confirmed that Maryland and South Carolina did not publish any reports in this period as there was no state regulation over B\&Ls. The other states likely did not publish reports either, but it is difficult to obtain confirmation of a negative.
} 
(Maryland, Oklahoma, Pennsylvania, and South Carolina) or did not distinguish among loan contracts in their published balance sheets (California, Kentucky, Michigan, and Missouri). While we cannot fully characterize the adoption pattern during the 1930s in these states, we generally have strong evidence on whether direct reduction loans were used prior to the Depression in each.

Two of these states, California and Maryland, likely had substantial use of direct reduction loans prior to the Depression. Maryland's B\&Ls appear to have introduced the direct reduction loan in the 1860s, as noted in section 2.4. A federal report written in 1937 regarding Baltimore's B\&Ls noted that the direct reduction contract had already been in widespread use prior to the Depression. In California, the extent of adoption before 1930 is a bit unclear. California state law allowed B\&Ls to make direct reduction loans as early as 1901, and Haveman, Paruchuri and Rao (2007) note that this occurred around the same time that guarantee stock organizational structures were adopted in the early 1900s. In the NBER sample, seven of the eight Californian lenders reported originating only direct reduction loans in the 1920s, but this may be biased upward.

Four states, Kentucky, Missouri, Oklahoma, and Pennsylvania, appear to have relied more or less exclusively on share accumulation loans prior to the 1930s. The NBER sample contains no loans from Kentucky, but does have two lenders in Missouri, three in Oklahoma, and four in Pennsylvania, and all report only share accumulation loans before 1935. The 1936 annual report of Missouri B\&Ls states that the direct reduction plan "is gradually usurping the old sinking fund plan in vogue for so many years in the industry... and is rapidly being adopted by State chartered institutions” (p. 10). Likewise, in Pennsylvania, federal surveys conducted around 1936 of Philadelphia, Pittsburgh, Scranton, Reading, Allentown, Bethlehem and Harrisburg indicate little adoption of direct reduction loans up to that point, though some adoption of direction reduction plans was noted in Erie. ${ }^{37}$ Federal surveys of Covington, Lexington, and Louisville Kentucky note the same pattern. For example, the 1936 Covington survey notes that some federal associations have introduced direct reduction loans, but "building and loan associations and their members have so long operated on the share reduction basis that most of them still continue this plan. ${ }^{38}$ In all of these states except Oklahoma, B\&Ls in these

\footnotetext{
${ }^{37}$ The quote on Philadelphia is from p. 22 of the HOLC report.

${ }^{38}$ The federal surveys referenced here were conducted by the HOLC in most of the largest metropolitan areas in the second half of the 1930s. These can be found in the City Survey Files, Records of the Home Owners' Loan
} 
states were predominantly of the serial form.

Finally, the historical record yields more limited information on the remaining two major states-Michigan and South Carolina. The NBER sample has no loans from South Carolina. A federal survey from the latter 1930s indicate that a small number of associations in Columbia, SC had offered direct reduction loans prior to the Depression, but "most" operated on the share accumulation plan. In Michigan, the NBER data do record some use of direct reduction loans during the 1920s. The federal surveys, however, give little indication that such practices were widespread. Since the NBER data do not cover any of the major Michigan cities, we suspect share accumulation loans were still dominant in Michigan prior to the Depression.

\subsection{Discussion}

The various data presented in this section allow an unprecedented look at the timing and the speed of the adoption process regarding direct reduction loans within the B\&L industry during the 1930s. The data reveal three important features of the adoption process that will be built on further in the final sections of this paper. First, there is a meaningful amount of variation in the pace of transition across states. New England states tended to exhibit slower adoptions, for example, while some states such as Louisiana show an early and near total commitment to direct reduction lending. This cross-state variability holds some potential for differentiating across hypotheses that could explain the transition to direct reduction loans. Second, federallychartered savings and loans already had a significant presence in the thrift industry by 1940, and could have had an important impact on the overall adoption process. Finally, it is important to note that the bulk of the activity documented here took place within the conventional (uninsured) loan market, i.e. without the involvement of FHA insurance, casting doubt on the importance of the FHA in spurring these changes in B\&L loan practice.

\section{Transition during Crisis}

The aggregate and state level data we have just examined indicates that the transition to

Corporation, Record Group 195.3, National Archives II, College Park, MD. Each of the reports cited here are available digitally from the authors. The Oklahoma reports are in box 41A, the Pennsylvania reports in boxes 30-32 and 93-96; the Kentucky reports in boxes 123-124; the South Carolina reports in box 97; and the Michigan reports in boxes 6-8, 17-19, and 23 . 
direct reduction loans became widespread and rapid during the 1930s. In this section we suggest that a simple cost/benefit framework can explain both the slow adoption before 1930 and the rapid adoption after 1930 . While the costs of adoption had been gradually falling before 1930 , the abrupt pickup in the pace of adoption during the Depression was driven by a sharp increase in the benefits of adoption, as the preferences of borrowers shifted away from the share accumulation contract based on its poor performance during the 1930s mortgage crisis.

The risk in share accumulation contracts derived from the requirement that borrowers' sinking funds remain invested in their associations' equity, and therefore its loan portfolio. As noted in section 2.3, financial weakness at a B\&L could cause dividends on that equity to fall, retained dividends to be taken away, or in a worst case scenario the equity itself to be written down. Industry leaders clearly understood the risks that borrowers faced before the 1930s. Clark and Chase, writing in 1925 (in a text commissioned by the main industry trade group to promulgate B\&L practices) noted these risks:

The periodical reduction plan has this advantage for the borrower: In the event of a failure of the association at any time after he has started to repay the loan, the borrower's liability is constantly growing less. If the affairs are thrown into liquidation, the borrower can only be held for the amount of the principal that remains charged to him...It is possible in the event of a failure under the regular [sinking fund] plan that all shares might lose their value and the borrower would still be liable for the total amount of his loan. (pp. 142-3)

Clark and Chase then dismissed these problems too easily:

The practice of crediting on the loan each of the separate payments, thus reducing the principal each month, instead of applying the payments on shares, may make a difference to the borrower from a legal standpoint in case the association fails. It makes very little practical difference because of the small likelihood of failure. (p. 255).

During the 1930s, these risks turned out to be much worse than described by Clark and Chase. In Newark, NJ, for example, one in three associations wiped out all of their borrowers' retained dividends. More than half of Newark’s B\&Ls ended up in liquidation before the end of the 1930s, while most of the others reorganized by writing down the value of their shares. ${ }^{39}$ Across the country, large numbers of foreclosures during the 1930s, driven by substantially lower housing prices and widespread unemployment, caused B\&Ls to lose sizable amounts of money. Mortgage foreclosures accelerated to a peak in 1933 but did not significantly decline until the late 1930s, and large segments of the B\&L industry remained in deep financial trouble for most of the decade. The widespread and severe nature of B\&L distress is important here as it helps

\footnotetext{
${ }^{39}$ See Rose (2012). The method of reorganization involved splitting assets and liabilities into two associations. One association received the bad assets, such as foreclosed real estate and delinquent loans, which would be slowly liquidated, and the shares placed into the bad association would only receive whatever the liquidation could produce.
} 
illustrate why borrower attitude shifted so widely in disfavor of the share accumulation contract.

Borrowing members had incentives in this situation to default on their loans not only because of their personal financial troubles, but also because further share purchases could be wiped out. Non-borrowing members likewise had good reason to stop investing funds and to apply for withdrawal from their associations. When funds to pay withdrawals ran out, a building and loan remained technically open, but became what was referred to as "frozen" as it slowly liquidated its loan and real estate portfolio and settled its share accounts. This interrupted the ability of borrowers to refinance elsewhere, as they were often not able to get credit for the amounts in their sinking funds, as that would essentially constitute a withdrawal. ${ }^{40}$

By 1934 an article in the official publication of the industry's national trade group reflects how quickly and dramatically these experiences changed attitudes about the traditional B\&L share accumulation loan:

...[A]n almost universally adopted principle in building and loan has in the short period of a few years become discredited to the extent that it is now rapidly becoming obsolete. I refer to the share plan loan. (Building and Loan Annals, 1934, p. 197)

As a result, potential loan customers became wary of B\&Ls:

Again, as this [the sinking fund loan] plan becomes understood, it is more difficult for associations to obtain the best mortgage loans...The difficulty of obtaining good loans is especially pronounced in areas where there are major reductions in dividend rates or where there have been failures or reorganizations of associations. It also becomes a greater problem where competitors citing unusual examples use them to discourage borrowers or prospective borrowers in even the best managed institutions using this plan. (Bodfish and Theobald, 1938, p. 183)

The Bodfish and Theobald quote suggests that the sudden increase in concern about the fragility of the share accumulation contract created market pressures for B\&Ls to adopt the direct reduction loan. To examine the possibility Figure 1 presents a scatterplot of the share of direct reduction loans held in the aggregate B\&L mortgage portfolio for sixteen states in 1945 against B\&L closure rates in those states between 1930 and 1940. The positive association between closures and adoption is consistent with the claim that market participants reweighed the relative advantages and drawbacks of the share accumulation contract as a result of the mortgage crisis. Given these trends, it is likely that the pressure from borrowers to adopt the direct reduction contracts would have intensified during the 1930s even in the absence of New Deal programs.

\footnotetext{
40 Rights of Depositors and Borrowers upon Insolvency of Building and Loan Associations Source: The Yale Law Journal, Vol. 42, No. 6 (Apr., 1933), pp. 931-941.
} 
Figure 1: Transition to Direct Reduction related to Closure Rates

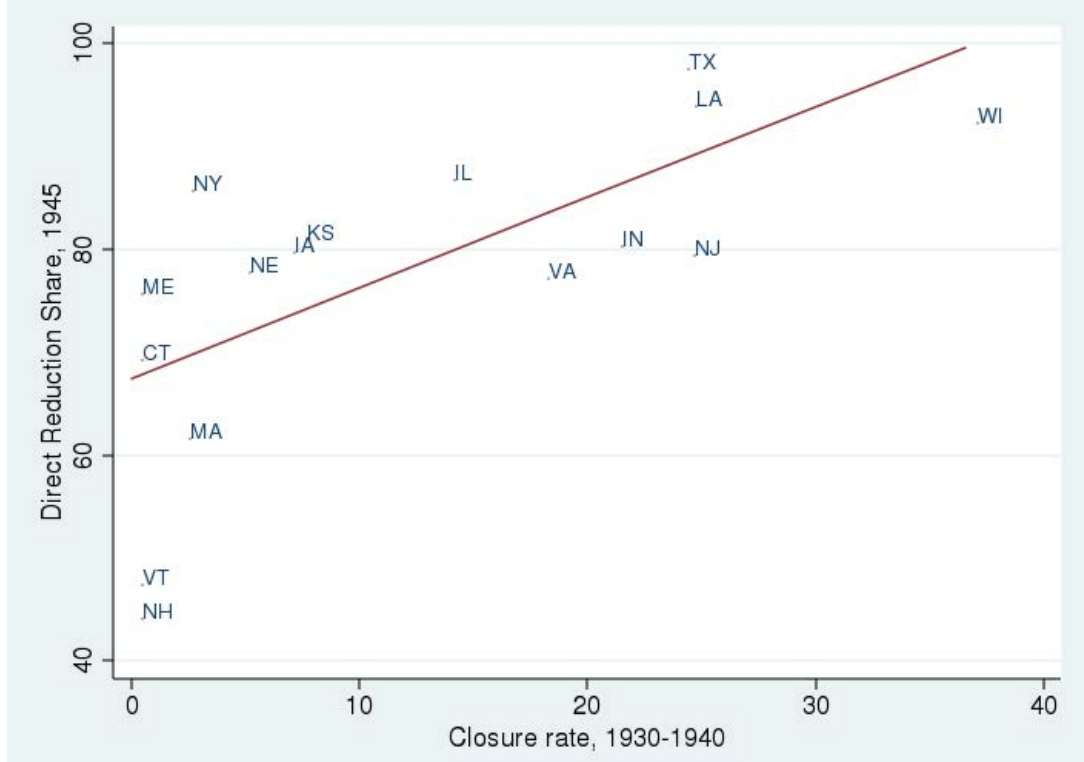

Notes: Closure rates include liquidations and state seizures but not reorganizations. Closure rates are compiled from the state-level annual reports.

The transition to direct reduction involved handling credit risk in new ways, and adopting new accounting methods and organizational forms. By 1930 the costs of doing so varied substantially across the nation, depending on an association's organizational form, its state's regulatory structure, and the characteristics of the savers that it served. These all evolved in different patterns across markets in the U.S. during the century-long process of innovation that we described earlier. Prior to the Depression, the costs of adopting direct reduction loans were substantial enough in most areas to outweigh the perceived benefits of switching to the direct reduction loan. Indeed, during the 1920s building boom, those B\&Ls that used share accumulation loans had little trouble attracting borrowers. This was especially true given that other types of lenders continued to offer borrowers only short-term loans with balloon payments or, at best, partial amortization. Within this environment, the B\&L industry expanded while continuing to rely most heavily, and in most markets, on the traditional share accumulation loan contract.

The differential cost of adopting direction reduction across association types is also reflected in the scatterplot in Chart 1. Serial associations dominated the B\&L industry in all of the New England states, for example, and the direct reduction loan was adopted more slowly 
there. ${ }^{41}$ For this region, of course, very low closure rates could also have played a determinative role. The interaction seems to also to have been at work in serial-dominated states that experienced more severe distress—-such as Illinois and New Jersey-where the benefits of moving away from share accumulation loans, as measured by closure rates, apparently outweighed the relatively high costs of restructuring liabilities. Wisconsin represents the situation in which a rapid transition to the direct reduction loan could be attributable either to the high rate of closures or to the relative ease of transitioning to direct reduction loans in a state where non-serial plan associations dominated. The fact that non-serial B\&Ls also dominated in Texas and Louisiana could also explain why the transition to direct reduction was more rapid in these states than in equally distressed, but serial-plan dominated, New Jersey.

The patterns in the scatterplot for these ten states suggest that the transition to the direct reduction loan in the 1930s reflected both costs and benefits. In this way this evidence is consistent with the view that the rapid transition to direct reduction in the 1930s was driven by the same forces that had pushed the innovation before 1930, albeit at a much more gradual pace. We learn much less from Chart 1, however, about the process for states like New York and Kansas in which a mixture of serial and non-serial associations operated and direct reduction lending had made inroads during the 1920s. But the organizational and accounting costs of adopting direct reduction contracts for types of B\&Ls were lowered during the 1930s by an extensive educational campaign conducted by B\&L trade associations, described in section 2.

\section{How the New Deal Mattered}

We have explained the adoption of direct reduction lending within the B\&L industry, thus far, without appealing directly to the New Deal programs that are popularly credited with introducing and establishing the amortized, long-term loan contract in the nation's residential mortgage market. In this section we clarify just how those New Deal programs affected the transition among the nation's thrifts. We focus on B\&Ls because they were the most important institutional source of residential mortgage credit both before and after the Depression, but acknowledge that New Deal programs likely affected other lenders in important ways. ${ }^{42}$

\footnotetext{
${ }^{41}$ This discussion refers to the 1924 enumeration of plans across states that is presented in Table XXXI of Clark and Chase (1925) 502-3.

${ }^{42}$ One institution we do not discuss below is the Federal National Mortgage Association (FNMA, or Fannie Mae), which was established in 1938 to help foster a secondary market in FHA loans. While Fannie Mae has become an
} 


\title{
5.1 Federal charters and FSLIC insurance
}

A new system of federal charters, first available in 1933, was influential in the transition to direct reaction lending. By 1936, federally-chartered S\&Ls were required to write only directreduction mortgage loans, and by 1941 more than 20 percent of B\&Ls/S\&Ls operated under federal charters and together they held 35 percent of the industry's assets. More than 800 of these institutions entered the federal system by converting from state charters, while the remaining 639 were originally organized as federal S\&Ls. ${ }^{43}$ The federal charters might have encouraged or sped up the transition to direct reduction for some lenders. Given the selection involved in the chartering program, however, the more important channel of influence was probably the competitive effect of federal savings and loans on the remaining state-chartered B\&Ls.

The decision by federal authorities to require direct reduction loans was made with consideration of the factors we have stressed in this paper, including the loss of credit-risk sharing inherent to share accumulation loans. A window into this decision making process is afforded by Horace Russell, the general counsel of the FHLB Board. After federal charters were authorized in June 1933, Russell met with a group of B\&L industry leaders to get feedback and enlist their cooperation before drafting the language of the actual charter. He initially proposed that federal associations be limited to holding only direct reduction loans and funding them with share accounts with no compulsory savings requirements. He left, however, with a compromise that allowed B\&Ls to retain traditional installment shares and loans already on their books:

\begin{abstract}
Another great debate arose over the terms and conditions of loans...[t]here was much objection to the abandonment of the Share Account Sinking Fund Loan which, of course, does give the corporation added strength because under the plan the borrowers absorb a part of the losses. We finally compromised...so that the Share Account Sinking Fund loans could be carried. (Russell, 1960, p. 64.)
\end{abstract}

This initial framework resulting from these discussions was referred to as Charter E. The transformation to direct reduction contracts within the B\&L industry was so rapid that, just three years later, the FHLB Board approved a new Charter K that required both direct reduction loans

institution of central importance to the modern mortgage market (along with Freddie Mac which established in 1970), its loan holdings were relatively small during the 1930s and limited to FHA loans, and its timing is too late to credibly explain the B\&L transition.

43 The Home Owners' Loan Corporation was charged with investing some $\$ 250$ million in the 1930s in the stock of new federal associations in areas not served by home mortgage lenders. The data on federal charters come from Snowden (2003) Table 3. 
and share savings accounts without objection. The dating of Russell's story to 1933 is important: it occurred just after Congress authorized the HOLC to make direct reduction loans (in fact federal charters were authorized in the same act but the loan plan was not specified), and before the creation of the FHA in 1934, and therefore casts doubt on the primacy of those two institutions in shaping the federal system that encouraged direct reduction lending.

From a financial innovation point of view, federal chartering requirements were responsive to and built on the transition already taking place in the industry. Without the experience of B\&Ls in Ohio and elsewhere, federal officials would have had less knowledge about how direct reduction contracts worked and likely would not have been as confident in requiring their use by all federal associations, or by the HOLC and FHA.

As we have stressed in this paper, it was important for associations to change their liability structure when adopting direct reduction loans, and federal charters facilitated this process by institutionalizing liability innovations developed by Ohio B\&Ls in the previous half century. Federal S\&Ls funded their loans with liabilities similar to the optional payment shares used in Ohio (called "share savings accounts"), which had deposit-like qualities and enabled the diversion of earnings into loss reserves. These accounts were also federally-insured through the Federal Savings and Loan Insurance Corporation, thereby eliminating the direct sharing of credit risk with insured non-borrowing savers. A federal charter, in other words, provided an entire framework for changing a B\&L's assets and liabilities so that it could make and fund direct reduction loans. These liability changes solidified the transition to the model developed in Ohio that was similar to savings banks and far removed from the structure of the original $B \& L$ terminating associations.

Federal charters required participation in the FSLIC, but insurance was also available to state chartered B\&Ls and could have assisted these B\&Ls in the transition to direct reduction lending. By 1941, in fact, about 40 percent of state-chartered associations were FHLB members and one-third of those also participated in the FSLIC program. At the state level, B\&Ls also began creating loss reserves that could absorb credit risk, parallel to the changes in the federal system. The New York Superintendent of Banking described his guidance to S\&Ls regarding the accumulation of such reserves:

A continued tendency has been shown toward the adoption of the direct reduction mortgage. This plan eliminates the issuance of shares to be pledged to secure mortgage loans and as a result the ratio of surplus and guaranty fund to shares may reflect an increase even in the absence of actual transfers from earnings. In view of the trend toward this method of operation, it is recommended that transfers from earnings to guaranty 
fund be continued until such fund equals $10 \%$ of share liability or $50 \%$ of real estate owned, whichever is greater, and that the maximum surplus accumulation to be permitted, be raised from $15 \%$ of share liability to 25\%. (New York, 1936, p. 5)

These loss reserves ("guaranty funds" in New York or "contingent reserves" elsewhere) on the liability side of balance sheets set aside earnings that could have been awarded to shareholders as dividends. The purpose was to smooth the returns paid to shareholders and to offset losses suffered by the association. The costs of undertaking this change depended on the organizational structure of an association, and it turned out that serial associations were particularly illprepared: ${ }^{44}$

In the serial and terminating associations, these [contingent] reserve funds are seldom found. In both of these types of associations, profits are allotted to shares in a group or series, and are at once reinvested by the association...” (Clark and Chase, 1925, p. 344)

Serial plan associations in particular had avoided reserve funds because it was difficult to allocate them across different groups of members who had contributed different amounts of foregone earnings over different time horizons.

\subsection{The HOLC and FHA Programs}

Thus far we have explained the timing and pattern of the transition to direct reduction lending within the B\&L industry without referencing the HOLC and FHA which, as we noted in the introduction, play an important role in the popular accounts. Between 1933 and 1936 the Home Owners' Loan Corporation wrote and held loans on one out of every ten owner-occupied nonfarm homes in the U.S. All of these were long-term (15-year) direct reduction loans. The program was designed to repair a distressed mortgage market by purchasing defaulted mortgage loans from private lenders and refinancing those loans on terms that distressed borrowers could fulfill. The FHA program, in contrast, was created in 1934 with an explicit mission to provide "a thorough reform in the home financing structure" by insuring long-term, high LTV loans designed to result in "a complete retirement of the mortgage by the means of small amortization payments at frequent intervals." 45 Participating lenders paid a premium into a mutual fund to

\footnotetext{
${ }^{44}$ There were very few terminating associations in operation in the 1930s, but these would also have faced problems adapting to the direct reduction loan. Recall that serial associations accounted for all members in groups, while direct reduction loans required individual accounts.

${ }^{45}$ First Annual Report of the Federal Housing Administration, 1935, p. 4.
} 
insure against the loss of principal on an approved loan. The idea was not new since private mortgage companies in the greater New York metropolitan area insured loans that they originated and sold to investors throughout the 1920s. ${ }^{46}$ What was new about FHA insurance was that it was only available for long-term, amortized loans.

Although the HOLC had a significant impact on the mortgage market and its recovery from crisis, its impact on the transition from share accumulation to direct reduction within the B\&L industry was indirect at best. The HOLC, to begin with, was a temporary program that made loans only during the three-year window that was specified in the original legislation. The corporation, moreover, could not originate entirely new loans but rather could only refinance existing loans. So while the HOLC was an enormously successful demonstration project for direct reduction lending, it could not influence mortgage lending terms by competing with private lenders. Clearly the HOLC did not invent the direct reduction loan, though perhaps it was the first to introduce the loan to many markets. The HOLC's use of this contract also reflects admiration for direct reduction loans that had already been in use primarily in the farm loan sector and also in segments of the B\&L industry as we have seen.

The B\&L industry sold more distressed loans to the HOLC than any lender group, but this is not surprising given that it was the nation's largest institutional source of residential real estate loans. As a share of its total mortgage loan portfolio, on the other hand, the HOLC bought fewer loans from B\&Ls than most other lenders and, as we have just seen, did not save the industry from a long, painful process of liquidation that lasted well past 1936.

Turning to the FHA, commercial banks, which relied almost exclusively on short-term balloon loans before 1930, were by far the biggest users of FHA insurance. Figure 2 shows that in 1935 they accounted for 70 percent of all FHA-insured loans originated that year, and about 45 percent of those originated in 1940. By 1940, 37 percent of the residential real estate loans held by national and state-chartered banks were FHA loans. ${ }^{47}$

The B\&L industry did not embrace the FHA nearly to the same extent. B\&Ls were in the early stages of their own transition from share accumulation to direct reduction loans when the FHA program was proposed in the National Housing Act of 1934. The industry did not, however, see federal insurance as a means of facilitating its transition. The program, instead,

\footnotetext{
${ }^{46}$ Snowden (2010).

${ }^{47}$ Sixth Annual Report of the Federal Housing Administration, 1940, 41-3.
} 
was seen as a mechanism through which other mortgage lenders, especially commercial banks, could enter the market for long-term real estate loans that B\&Ls had dominated for a century with its share accumulation plan. For this reason the industry's trade group, the US Building and Loan League, fought hard to defeat the program, but lost. ${ }^{48}$

Figure 2: Share of all FHA loans originated by different lender classes

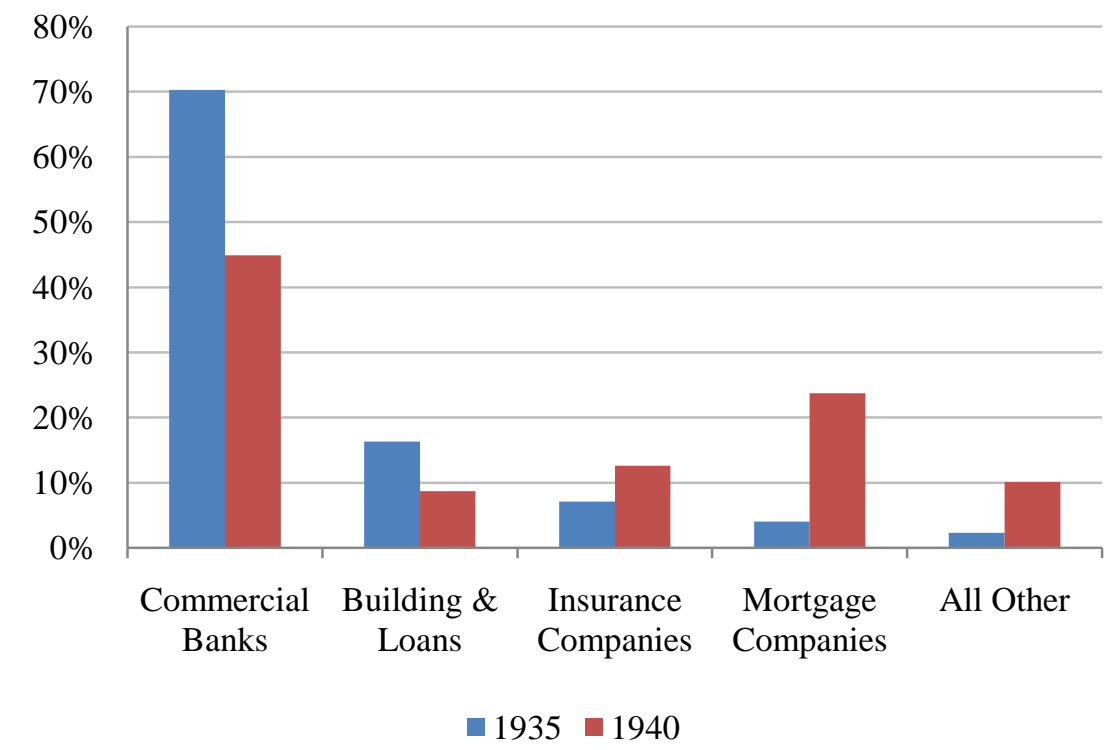

Notes: Each column is that lender's share of all FHA loans originated in each year. Therefore, the blue columns sum to one, as do the red columns. Source: Seventh Annual Report of the Federal housing Administration, p. 49.

After losing the battle, some within the industry experimented with FHA lending, but resistance against participation eventually won out. ${ }^{49}$ By the end of 1940, 1,700 out of nearly 7,000 B\&Ls had made at least one federally-insured loan, but by 1940 only 789 participated in the program. ${ }^{50}$ At that date, moreover, FHA loans represented only about 5 percent of the total B\&L loan portfolio. Figure 2 shows another measure of the B\&Ls' low and declining profile in the FHA program; by 1940 the industry originated less than 10 percent of all FHA mortgage loans although it remained the nation's largest residential home mortgage lender. More research would be useful regarding whether competition from FHA loans in local markets encouraged

\footnotetext{
${ }^{48}$ Ewalt (1962) pp. 137-142.

${ }^{49}$ Ewalt (1962) pp. 140-144 argues that ideological opposition among B\&Ls to FHA's public-private model accounts for B\&Ls resistance to the program. The close connection between B\&Ls and local home builders who did not want to conform to FHA strict building codes represents an interesting, but as yet untested, alternative explanation.

${ }^{50}$ FHA Annual Report (1940) p. 52.
} 
B\&Ls to adopt direct reduction loans.

The lack of B\&L participation in the FHA has important implications for our broader understanding of the diffusion of the modern residential loan contract in the United Sates. A glaring deficiency in popular explanations of this process is a failure to recognize that the longterm, amortized mortgage was integrated during the 1930s not only into the federally-insured but also the conventional (uninsured) mortgage loan market. B\&Ls were an integral component of the conventional market which, as can be seen in Figure 3, accounted for more than 80 percent of residential mortgages before 1940 and the large majority of it thereafter.

Figure 3: Share of all residential real estate loans that were insured by the FHA or VA

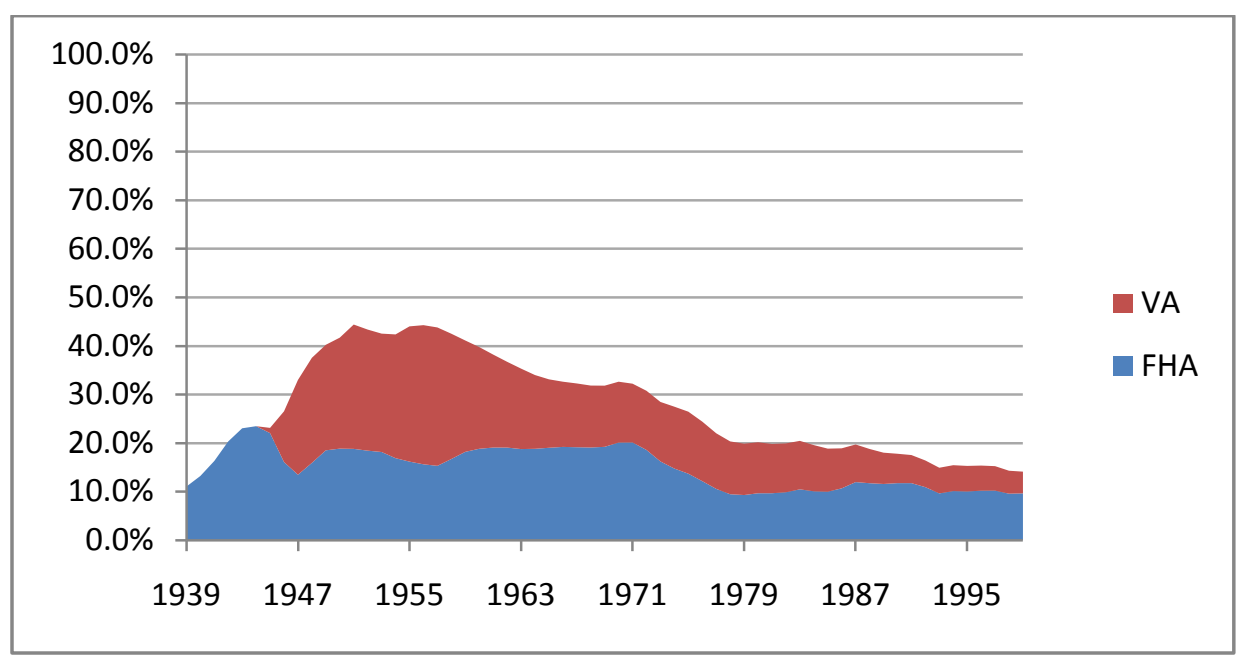

Source: Historical Statistics of the United States, Millennial Edition, Series DC292 - DC948

Despite the modest participation of B\&Ls in federally-insured loan market, the FHA loan program could have had a competitive impact on B\&Ls that helped to encourage adoption of direct reduction loans. B\&L leaders frequently commented on this competition, in fact, when discussing changes in their own contracts. Both the HOLC and FHA familiarized lenders and borrowers with the long-term, direct reduction loan, and subsidized its use. In doing so the programs created a competitive environment which encouraged all lenders, including B\&Ls, to adopt direct reduction loans. We have referred to the view that the HOLC and FHA were of primary importance as the popular understanding, and while that misses much of the story for B\&Ls, it is a reasonable interpretation of the diffusion process that took place among commercial banks and life insurance companies, as both groups took up FHA lending quickly. 
The adoption of direct reduction lending among B\&Ls in the conventional mortgage market during the same period, in marked contrast, represented an acceleration of a decades-long process of financial innovation.

\section{Conclusion}

This paper is the first serious attempt to characterize, in the conventional mortgage market, the historical use of the direct reduction contract, a key financial innovation in the field of real estate lending. Gathering data from the 1890s, 1920s, and 1930s, we have shown that direct reduction contracts were slowly adopted by the B\&L industry in the fifty years prior to the Great Depression, and then rapidly and extensively taken up during the 1930s.

This paper alters the conventional wisdom regarding the origins of direct reduction loans in two important ways. First, prior to the Depression, loan plans were not limited to short term balloon loans as building and loan associations, the largest institutional source of residential real estate loans, offered contracts with long terms and detailed repayment provisions. Second, the direct reduction contract is not a creature of the 1930s, as it had been used to a moderate extent as far back as the 1880s in the residential real estate loan market in the US, earlier in England, and was also in use within the farm loan market.

To explain the rapid adoption during the 1930s, therefore, is a matter of the economics of adopting an existing piece of technology, and can be approached using ideas from the literature on the history of technology. The slow-then-fast adoption pattern is not dissimilar to those characterizing other inventions historically. To explain this, we take to heart the lesson of Rosenberg (1982) that the relevant unit of innovation is rarely a single invention, but rather a set of complementary innovations, often accumulated incrementally. In this case, we stress that direct reduction contracts were made possible by a host of other changes in the organizational and economic structure of B\&L associations from 1830 to 1930.

Importantly, this approach clarifies the role of the New Deal. An important vehicle for change was the creation of the new Federal Savings \& Loan system which provided a contractual and organizational template designed specifically for direct reduction lending. We have shown here that the federal structure incorporated, and therefore was built upon, innovations that had been introduced by the early B\&L adopters of direct reduction lending. The transition among B\&Ls that retained state charters was perhaps even more important given the greater loan 
volume held by state-chartered B\&Ls. The FSLIC insurance program also helped both state- and federally-chartered B\&Ls (and S\&Ls) restructure their liabilities in order to cope with the changes in credit risk allocation and loss of mutuality inherent to dropping the older share accumulation contracts. In contrast, participation in the new FHA loan insurance program was much less important to the transition to direct reduction contracts by building and loan associations, though the competitive effects of the program on B\&Ls surely mattered. Altogether, the New Deal assisted and encouraged the transition to direct reduction lending in the conventional mortgage market by building upon and encouraging an ongoing process of financial innovation. That process, however, was already being rapidly altered by the sudden, Depression-induced unpopularity of traditional B\&L contracts.

The mortgage crisis that began in 2007 is worse than any mortgage crisis in the United States since the 1930s. Like the Depression crisis, it has raised questions and uncertainty about how residential mortgage contracts should be written and financed. Today, the dominant mortgage contract is the fixed rate, long-term, fully amortized contract that was first used on a widespread basis in the home mortgage market during the 1930s. Popular explanations of this transition during the 1930s may mislead modern discussions, as they date both the invention and adoption of this contract to the 1930s. These explanations therefore imply that the contract was adopted either because it was recognized as more efficient than existing contracts or because of subsidies from the federal government. Either story would have interesting implications for today, but neither is necessarily true. While FHA subsidies were likely important for the adoption of amortization by other lenders, B\&Ls adopted direct reduction loans largely without such subsidies. In addition, we have explained the adoption process through a cost-benefit calculation that implies little about the general efficiency of one contract over another, and instead explains the quick transition during the 1930s by appealing to how existing contracts became unsustainable. This framework can also incorporate the fact that direct reduction contracts were invented far before 1930. Altogether, our approach emphasizes that the choice of loan contract should not be considered in isolation, but rather as one part of lenders' broader financial structures which govern how the risks of real estate loans are borne. The treatment of those risks is a subject that is as important today as it was in the 1930s. 


\section{Appendix: Geographic Distribution of NBER Sample}

Table A: Geographic distribution of the NBER sample

\begin{tabular}{lccccc}
\hline \hline & $\begin{array}{c}\text { Share of } \\
\text { national } \\
\text { B\&L }\end{array}$ & $\begin{array}{c}\text { Share of } \\
\text { loans in }\end{array}$ & & Share of & \\
& assets in & NBER & & national & Share of \\
S\&L & loans in \\
assets in & NBER \\
State & 1930 & sample & State & 1930 & sample \\
\hline Pennsylvania & 15.5 & 3.2 & & (continued) & \\
Ohio & 14.1 & 18.6 & Arkansas & 0.5 & 1.3 \\
New Jersey & 13.7 & 1.8 & Minnesota & 0.5 & 0.8 \\
Massachusetts & 6.4 & 7.9 & West Virginia & 0.4 & 0.0 \\
California & 5.8 & 9.9 & Rhode Island & 0.4 & 0.0 \\
Illinois & 5.3 & 8.7 & Oregon & 0.3 & 0.0 \\
New York & 5.0 & 9.3 & Alabama & 0.3 & 0.0 \\
Indiana & 3.5 & 9.3 & South Carolina & 0.3 & 0.0 \\
Wisconsin & 3.3 & 0.0 & Connecticut & 0.3 & 0.0 \\
Maryland & 2.5 & 1.0 & Maine & 0.3 & 1.5 \\
Missouri & 2.4 & 2.1 & Montana & 0.2 & 0.0 \\
Louisiana & 2.1 & 0.0 & Mississippi & 0.2 & 0.0 \\
Michigan & 1.9 & 3.4 & Tennessee & 0.2 & 0.0 \\
Nebraska & 1.7 & 0.0 & Florida & 0.2 & 0.0 \\
Oklahoma & 1.6 & 6.1 & Delaware & 0.2 & 0.0 \\
Texas & 1.5 & 1.0 & New Hampshire & 0.2 & 0.6 \\
Kansas & 1.5 & 2.4 & North Dakota & 0.2 & 0.4 \\
Kentucky & 1.3 & 0.8 & Wyoming & 0.1 & 0.0 \\
Washington & 1.2 & 4.4 & South Dakota & 0.1 & 0.0 \\
North Carolina & 1.0 & 0.0 & Georgia & 0.1 & 0.0 \\
District of Columbia & 0.9 & 1.4 & Idaho & 0.1 & 0.0 \\
Virginia & 0.7 & 0.0 & New Mexico & 0.1 & 1.6 \\
Colorado & 0.7 & 0.0 & Arizona & 0.1 & 0.0 \\
Utah & 0.6 & 0.0 & Vermont & 0.1 & 0.0 \\
Iowa & 0.6 & 2.6 & Nevada & 0.0 & 0.0 \\
\hline \hline
\end{tabular}

Notes: Data on assets in 1930 are taken from Bodfish (1931). 


\section{Appendix: Data Sources}

The data used in this paper come from the following annual reports issued by the various state regulators of building and loan associations.

Connecticut: Office of the Banking Commissioner, Report of the Bank Commissioner.

Iowa: Auditor of the State, Report of the State Auditor and Report on the Condition of Building and Loan Associations.

Illinois: Auditor of Public Accounts, Annual report of Mutual Building, Loan and Homestead Associations.

Indiana: Department of Banking, Annual Report of the Department of Banking.

Kansas: State Building and Loan Department, Annual Report of the Kansas Building and Loan Associations.

Louisiana: State Bank Commissioner and Supervisor of Homestead and Building and Loan Associations, Biennial Report Relative to State Banks, Savings Banks, Trust Companies, and Homestead and Building and Loan Associations, and Credit Unions.

Maine: Bank Commissioner, Report of the Bank Commissioner of the Condition of Savings Banks, Trust and Banking Companies, Loan and Building Associations, and Loan Companies.

Massachusetts: Department of Banking and Insurance, Annual Report of the Commissioner of Banks, Part III, Relating to Co-operative Banks and Savings and Loan Associations.

Missouri: Bureau of Building and Loan Supervision, Annual Report.

Nebraska: Department of Trade and Commerce, Report of the Department of Trade and Commerce.

New Hampshire: Board of Bank Commissioners, Annual Report.

New Jersey: Department of Banking and Insurance, Annual Report of the Commissioner of Banking and Insurance Relative to Building and Loan Associations.

New York: Banking Department, Annual Report of the Superintendent of Banks Relative to Savings and Loan Associations.

Ohio: Department of Commerce, Annual Report of the Superintendent of Building and Loan Associations.

Texas: Department of Banking, Annual Report of Building and Loan Associations.

Virginia: State Corporation Commission, Annual Report Showing the Condition of Incorporated State Banks and Other Institutions.

Vermont: Department of Finance, Annual Report of the Bank Commissioner.

Wisconsin, State Banking Department, Annual Report of the Wisconsin Building and Loan Associations, Credit Unions, and Investment Associations. 


\section{References}

American Building Association News, various issues.

Behrens, Carl F. (1952). Commercial Bank Activities in Urban Mortgage Financing. New York: National Bureau of Economic Research.

Bodfish, Henry Morton (1931). History of Building and Loan in the United States. Chicago: United States Building and Loan League.

Bodfish, Henry Morton and Adrian Daniel Theobald (1938). Savings and Loan Principles. New York: Prentice-Hall.

Building and Loan Guide and Bulletin, various issues.

Carliner, Michael S. (1998). “Development of Federal Homeownership 'Policy,”” Housing Policy Debate, vol. 9, no. 2, pp. 299-321.

Center for American Progress (2011). “A Responsible Market for Housing Finance.” http://www.americanprogress.org/issues/2011/01/pdf/responsiblemarketforhousingfinance.pdf

Clark, Horace Frisby and Frank A. Chase (1927). Elements of the Modern Building and Loan Associations. New York: Macmillan.

Colean, Miles (1944). American Housing. The Twentieth Century Fund: New York.

Emmons, William R (2008). “The Past, Present and Future of the U.S. Mortgage Market,” Central Banker, Summer 2008.

Ewalt, Josephine Hedges (1962). A Business Reborn: the Savings and Loan Story. Chicago: American Savings and Loan Institute Press.

Federal Home Loan Bank Board, Annual Report, Washington, D.C., various years.

Federal Home Loan Bank Board, Federal Home Loan Bank Review, various issues.

Green, Richard K. and Susan M. Wachter (2005). “The American Mortgage Market in Historical and International Context,” Journal of Economic Perspectives, vol. 19, no. 4, pp. 93-114.

Gruenberg, Martin J. (2007). Remarks at the 2007 Annual Meeting of the European Forum of Deposit Insurers. http://1.usa.gov/R6QaEI

Herrick, Myron, and R. Ingalls (1915). Rural Credits. New York: D. Appleton.

Jaffee, Dwight M (1975). “Innovations in the Mortgage Market” in Financial Innovation, edited by William L. Silber. Lexington: Lexington Books.

Haveman, Heather A., Srikanth Paruchuri, and Hayagreeva Rao (2007). "The Winds of Change: The Progressive Movement and the Bureaucratization of Thrift,” American Sociological Review, vol. 72, pp. 117-142. 
Mason, David L (2004). From Building and Loan to Bail-out. Cambridge: Cambridge University Press.

Riegel, Robert and J. Russell Doubman (1927). The Building and Loan Association. John Wiley \& Sons, New York.

Rose, Jonathan (2011). "The Prolonged Resolution of Troubled Real Estate Lenders During the 1930s.” Federal Reserve Board FEDS Working Paper 2012-31, http://www.federalreserve.gov/pubs/feds/2012/201231/201231abs.html

Rosenberg, Nathan (1982). Inside the Black Box: Technology and Economics. Cambridge: University Press.

Russell, Horace (1960). Savings and Loan Associations. Albany: Matthew Bender and Co.

Saulnier, Raymond J. (1950). Urban Mortgage Lending By Life Insurance Companies. New York: National Bureau of Economic Research

Savings and Loan News, various issues.

Schwartz, Carl Herbert (1938). Financial Study of the Joint Stock Land Banks. Washington, DC: Washington College Press.

Scratchley, Arthur (1849). A Treatise on Benefit Building Societies, London: John W. Parker.

Snowden, Kenneth (1997). "Building and Loan Associations in the U.S., 1880-1893: the Origins of Localization in the Residential Mortgage Market," Research in Economics, vol. 51 pp. 227-250.

Snowden, Kenneth (2003). “The Transition from Building and Loan to Savings and Loan,” pp. 157-206 in Finance, Intermediaries and Economic Development, edited by S. Engerman, P. Hoffman, J. Rosenthal, and K. Sokoloff. Cambridge: Cambridge University Press.

Snowden, Kenneth (2010). "Covered Farm Mortgage Bonds in the Late Nineteenth Century U.S.,” Journal of Economic History, vol. 70, no. 4. pp. 783-812.

Studenski, Paul and Herman Krooss (1963). Financial History of the United States. New York: McGraw-Hill.

United States Building \& Loan League (various years). Building and Loan Annals. Chicago.

U.S. Federal Housing Administration (various years). Annual Report of the Federal Housing Administration. Government Printing Office: Washington, D.C.

Wright, Carol (1893). Ninth Annual Report of the Commissioner of Labor: Building and Loan Associations. Washington, DC: Government Printing Office.

Zandi, Mark and Cristian deRitis (2011). The Future of the Mortgage Finance System, Moody's Analytics Special Report. http://bit.ly/eDlFaW 